\title{
Characterization of a GHF45 cellulase, AkEG21, from the common sea hare Aplysia kurodai
}

\author{
Mohammad M. Rahman ${ }^{1,2}$, Akira Inoue ${ }^{1}$ and Takao Ojima ${ }^{1 *}$ \\ ${ }^{1}$ Laboratory of Marine Biotechnology and Microbiology, Division of Applied Marine Life Science, Graduate School of Fisheries Sciences, Hokkaido University, \\ Hakodate, Japan \\ 2 Department of Fisheries Biology and Genetics, Bangladesh Agricultural University, Mymensingh, Bangladesh
}

\section{Edited by:}

Antonio Trincone, Istituto di Chimica Biomolecolare, Italy

\section{Reviewed by:}

Joana Costa, Center for

Neuroscience and Cellular Biology, Portugal

Irina Bakunina, G.B. Elyakov Pacific Institute of Bioorganic Chemistry,

Russia

\section{*Correspondence:}

Takao Ojima, Laboratory of Marine Biotechnology and Microbiology

Division of Applied Marine Life

Science, Graduate School of

Fisheries Sciences, Hokkaido University, 3-1-1 Minato-cho,

Hakodate, Hokkaido 041-8611, Japan

e-mail: ojima@fish.hokudai.ac.jp
The common sea hare Aplysia kurodai is known to be a good source for the enzymes degrading seaweed polysaccharides. Recently four cellulases, i.e., 95, 66, 45, and $21 \mathrm{kDa}$ enzymes, were isolated from $A$. kurodai (Tsuji et al., 2013). The former three cellulases were regarded as glycosyl-hydrolase-family 9 (GHF9) enzymes, while the $21 \mathrm{kDa}$ cellulase was suggested to be a GHF45 enzyme. The $21 \mathrm{kDa}$ cellulase was significantly heat stable, and appeared to be advantageous in performing heterogeneous expression and protein-engineering study. In the present study, we determined some enzymatic properties of the $21 \mathrm{kDa}$ cellulase and cloned its cDNA to provide the basis for the protein engineering study of this cellulase. The purified $21 \mathrm{kDa}$ enzyme, termed AkEG21 in the present study, hydrolyzed carboxymethyl cellulose with an optimal pH and temperature at 4.5 and $40^{\circ} \mathrm{C}$, respectively. AkEG21 was considerably heat-stable, i.e., it was not inactivated by the incubation at $55^{\circ} \mathrm{C}$ for $30 \mathrm{~min}$. AkEG21 degraded phosphoric-acid-swollen cellulose producing cellotriose and cellobiose as major end products but hardly degraded oligosaccharides smaller than tetrasaccharide. This indicated that AkEG21 is an endolytic $\beta-1$,4-glucanase (EC 3.2.1.4). A cDNA of 1013 bp encoding AkEG21 was amplified by PCR and the amino-acid sequence of 197 residues was deduced. The sequence comprised the initiation Met, the putative signal peptide of 16 residues for secretion and the catalytic domain of 180 residues, which lined from the N-terminus in this order. The sequence of the catalytic domain showed 47-62\% amino-acid identities to those of GHF45 cellulases reported in other mollusks. Both the catalytic residues and the N-glycosylation residues known in other GHF45 cellulases were conserved in AkEG21. Phylogenetic analysis for the amino-acid sequences suggested the close relation between AkEG21 and fungal GHF45 cellulases.

Keywords: Aplysia kurodai, AkEG21, endo- $\beta-1,4-$ glucanase, cellulase, GHF45, cDNA cloning, primary structure, phylogenic analysis

\section{INTRODUCTION}

Cellulose, a structural polysaccharide comprising 1,4-linked $\beta$-D-glucopyranose residues, exists mainly in plant cell wall as crystalline microfibrils (Jagtap and Rao, 2005). Since plant cellulose accounts for almost a half of total carbohydrate biomass on the Earth, intensive uses of the cellulose are expected to solve various problems that we are facing in ecological, environmental and energy fields (Agbor et al., 2011; Yang et al., 2011). In this respect, degradation of cellulosic materials by cellulose-degrading enzymes will be a fundamentally important technique because the cellulose-degrading enzyme can convert insoluble cellulose to soluble oligosaccharides and glucose without consuming high energy and producing hazardous byproducts (Michel and Czjzek, 2013; Ojima, 2013; Tsuji et al., 2013). The resulted sugars are applicable for foods, feeds, pharmaceutics, fermentation substrates, etc.

Complete enzymatic degradation of cellulose is usually achieved by the collaborative actions of three enzymes, namely,
(1) endo- $\beta-1,4$-glucanase (EC 3.2.1.4) which randomly cleaves internal $\beta$-1,4-linkages of amorphous regions in cellulose fibers, (2) cellobiohydrolase (EC 3.2.1.91) which releases cellobiosyl unit from non-reducing end of cellulose chain, and (3) $\beta$-D-glucosidase (EC 3.2.1.21) which releases glucose unit from cello-oligosaccharides (Lynd et al., 2002; Perez et al., 2002; Bayer et al., 2004). Although individual enzyme alone cannot completely depolymerize crystalline cellulose, the synergistic action of three enzymes efficiently promotes the depolymerization of cellulose. Among the three enzymes, endo- $\beta-1,4$-glucanase is the primarily important for the depolymerization of cellulose since it first acts on cellulose and provides new substrate sites for cellobiohydrolase and $\beta$-D-glucosidase. Accordingly, endo- $\beta-1,4-$ glucanase is generally called "cellulase." Fungal and microbial cellulases have already been used in various purposes, e.g., detergent, textile, food, paper, pulp, brewing and winery (Sheehan and Himmel, 1999; Bhat, 2000; Zaldivar et al., 2001; Kuhad et al., 2011; Mojsov, 2012). Cellulases are also expected as a biocatalyst 
in the production of biofuels from cellulose. If fermentable sugars can be produced from unused cellulosic materials at low cost, food-fuel conflicts in the bioethanol production using edible crops will be circumvented.

Cellulase distributes over various organisms, e.g., archaea (Gueguen et al., 1997; Li et al., 2003), bacteria (Tomme et al., 1995; Hong et al., 2002; Masuda et al., 2006; Fibriansah et al., 2007), fungi (de la Cruz et al., 1995; Tomme et al., 1995), plants (Pesis et al., 1978; Castresana et al., 1990), and herbivorous invertebrates such as termite, cockroach, crayfish and mollusks (Watanabe et al., 1998; Yan et al., 1998; Byrne et al., 1999; Tokuda et al., 1999; Watanabe and Tokuda, 2001; Xu et al., 2001; Sugimura et al., 2003; Suzuki et al., 2003; Davison and Blaxter, 2005; Nishida et al., 2007; Sakamoto et al., 2007; Sakamoto and Toyohara, 2009; Tsuji et al., 2013). Previously, cellulase activities detected in the invertebrate animals were considered to be originated from symbiotic microbes in their digestive tracts or contamination by foods (Cleveland, 1924; Martin and Martin, 1978). However, recent biochemical and genomic studies have revealed that cellulases found in insects, crustaceans, annelids, mollusks, echinoderms and nematodes are their own gene products.

To date, a large number of primary structures of cellulases have been enrolled in CAZy data base (Cantarel et al., 2009). These cellulases have been classified under GHF (glycosyl hydrolase family) $5,6,7,8,9,10,11,12,26,44,45,48,51$, and 74 on the basis of hydrophobic cluster analysis for amino-acid sequences (Henrissat et al., 1989; Henrissat, 1991; Henrissat and Bairoch, 1993). Invertebrate cellulases are enrolled in five families, i.e., GHF5 (nematodes: Globodera rostochiensis and Heterodera glycines; Smant et al., 1998), GHF6 (sea squirt: Ciona savignyi; Matthysse et al., 2004), GHF9 (termite: Reticulitermes speratus, Watanabe et al., 1998; abalone: Haliotis discus hannai, Suzuki et al., 2003; sea urchin: Strongylocentrotus nudus, Nishida et al., 2007), GHF10 (freshwater snails: Ampullaria crossean, Wang et al., 2003; Pomacea canaliculata, Imjongjirak et al., 2008), and GHF45 (bivalve: Mytilus edulis, Xu et al., 2001; freshwater snail: A. crossean, Guo et al., 2008; freshwater bivalve: Corbicula japonica, Sakamoto and Toyohara, 2009). Among these cellulases, GHF9-type cellulases appear to be most widespread in nature and well characterized (Davison and Blaxter, 2005). In molluscan cellulases, GHF9 enzyme was identified in H. discus hannai (Suzuki et al., 2003) and A. kurodai (Tsuji et al., 2013), while both GHF10 and GHF45 enzymes were identified in P. canaliculata (Imjongjirak et al., 2008) and A. crossean (Ding et al., 2008), and GHF45 enzymes were identified in M. edulis (Xu et al., 2001), A. crossean (Guo et al., 2008), C. japonica (Sakamoto and Toyohara, 2009) and A. kurodai (Tsuji et al., 2013). Some mollusks possess plural cellulases, e.g., GHF9 and GHF45 cellulases (Sakamoto et al., 2007; Guo et al., 2008; Li et al., 2009; Sakamoto and Toyohara, 2009; Tsuji et al., 2013). The synergistic action of multiple enzymes appeared to improve the production of glucose from seaweed cellulose (Tsuji et al., 2013). Among the molluscan cellulases, GHF45 enzyme has been characterized by its smaller molecular size compared with other cellulases. Namely, the molecular size of GHF45 enzymes is $\sim 25 \mathrm{kDa}$, while those of GHF9 and GHF10 enzymes are $45-63 \mathrm{kDa}$. The small size of GHF45 cellulases appeared to be advantageous in performing protein-engineering and crystallography studies, since low molecular mass proteins are usually heat stable and easily produced by heterogeneous expression systems. Actually, the GHF45-type cellulase CjCel45 from freshwater clam was successfully produced by the Escherichia coli expression system (Sakamoto and Toyohara, 2009) and the three-dimensional structure of Cel45A from $M$. edulis could be analyzed by X-ray crystallography (PDB ID, 1WC21006).

To date, GHF45 cellulase genes have been identified only in a few mollusks (Xu et al., 2001; Guo et al., 2008; Sakamoto and Toyohara, 2009) and enzyme proteins have been isolated only from M. edulis (Xu et al., 2000), A. crossean (Li et al., 2005), and A. kurodai (Tsuji et al., 2013). Molluscan GHF45 cellulases were suggested to be acquired by horizontal gene transfer from fungi by phylogenetic analyses (Scholl et al., 2003; Kikuchi et al., 2004; Sakamoto and Toyohara, 2009); however, accumulation of primary structure data seems to be still insufficient for detailed discussion about the origin and molecular evolution of molluscan GHF45 cellulases.

The common sea hare A. kurodai is a good source for polysaccharide-degrading enzymes since it harbor much digestive fluid in gastric lumen (Kumagai and Ojima, 2009; Rahman et al., 2010; Zahura et al., 2010; Tsuji et al., 2013; Kumagai et al., 2014). Recently, four cellulase isozymes, i.e., 21, 45, 66, and 95 $\mathrm{K}$ cellulases, were isolated from the digestive fluid of $A$. kurodai (Tsuji et al., 2013). Among these enzymes, the $21 \mathrm{~K}$ enzyme was suggested to be GHF45 cellulase. We also had noticed that the digestive fluid of $A$. kurodai contained plural cellulases and the smallest enzyme was of $\sim 21 \mathrm{kDa}$. This enzyme was considered to correspond to the $21 \mathrm{~K}$ cellulase reported by Tsuji et al. (2013). Although partial amino-acid sequences of the $21 \mathrm{~K}$ cellulase were reported, no entire primary structure has been determined yet.

In the present study, we isolated the $\sim 21 \mathrm{kDa}$ enzyme from the digestive fluid of $A$. kurodai and investigated its general properties. Further, we cloned the cDNA encoding this enzyme and confirmed that this enzyme is a member of GHF45. This cDNA will provide the basis for protein-engineering studies on Aplysia GHF45 cellulase.

\section{MATERIALS AND METHODS MATERIALS}

Sea hares identified as A. kurodai (average body length and weight; $\sim 15 \mathrm{~cm}$ and $\sim 400 \mathrm{~g}$, respectively) were collected in the shore of Hakodate, Hokkaido Prefecture of Japan in July 2012. Approximately $112 \mathrm{~mL}$ of digestive fluid was obtained from the gastric lumen of 14 animals after dissection. The digestive fluid was dialyzed against $2 \mathrm{mM}$ sodium phosphate buffer ( $\mathrm{pH} 7.0$ ) for $2 \mathrm{~h}$ and centrifuged at $10,000 \times \mathrm{g}$ for $10 \mathrm{~min}$ to remove insoluble materials. The supernatant (crude enzyme) was used for purification of cellulase. Carboxymethyl cellulose (CMC, medium viscosity) was purchased from ICN Bio medicals, Inc. (OH, USA). TOYOPEARL CM-650M was purchased from Toyo Soda Mfg, Co. (Tokyo, Japan) and Superdex 200 10/300 GL from GE Healthcare UK Ltd. (Little Chalfont, Buckingham shire, England). Cellooligosaccharides (disaccharide - hexasaccharide, G2 - G6) were prepared by limited acid hydrolysis. Briefly, $1 \mathrm{~g}$ of cellulose powder (Wako Pure Chemical Industries Co. Ltd. 
Osaka, Japan) was hydrolyzed with $100 \mathrm{~mL}$ of $0.2 \mathrm{~N} \mathrm{HCl}$ at $100^{\circ} \mathrm{C}$ for $1 \mathrm{~h}$, and the supernatant containing cellulose fragments was neutralized with $1 \mathrm{~N} \mathrm{NaOH}$. Approximately $50 \mathrm{mg}$ of cellulose fragments were subjected to gel-filtration through a column of BioGel-P2 $(2 \times 100 \mathrm{~cm})$ and cellooligosaccharides were separately eluted with $10 \mathrm{mM}$ sodium phosphate buffer $(\mathrm{pH} 7.0)$ and stored at $-20^{\circ} \mathrm{C}$ until use. RNAiso Plus and Oligotex dT30 were purchased from TaKaRa (Tokyo, Japan). cDNA synthesis kit and $5^{\prime}$ - and $3^{\prime}$-Full RACE kits were purchased from TaKaRa and TA-PCR cloning kit comprising pTAC-1 and E. coli DH5 $\alpha$ was from Biodynamics (Tokyo, Japan). Restriction endonucleases, T4 DNA ligase, agarose, E. coli strain DH5 $\alpha$ were purchased from TaKaRa. AmpliTaq Gold PCR Master Mix and BigDyeTerminator Cycle Sequencing kit were from Applied Biosystems (Foster city, CA, USA). Bacto-tryptone, Bacto-yeast extract and other reagents were from Wako Pure Chemicals Industries Ltd. (Osaka, Japan).

\section{PURIFICATION OF A. KURODAI CELLULASE}

Crude enzyme from A. kurodai $(\sim 100 \mathrm{~mL})$ was first subjected to ammonium sulfate fractionation. Cellulase activity was detected in the fraction precipitated between 40 and $60 \%$ saturation of ammonium sulfate. This fraction was collected by centrifugation at $10,000 \times \mathrm{g}$ for $20 \mathrm{~min}$, dissolved in and dialyzed against $10 \mathrm{mM}$ sodium phosphate buffer ( $\mathrm{pH} 7.0$ ) for $24 \mathrm{~h}$. The dialysis bag was changed every $2 \mathrm{~h}$ to avoid puncturing by cellulase action. The dialysate was then applied to a TOYOPEARL CM-650M column $(1.5 \times 20 \mathrm{~cm})$ pre-equilibrated with the same buffer. Proteins adsorbed to the column were developed by linear gradient of $\mathrm{NaCl}$ from 0 to $0.3 \mathrm{M}$. Fractions showing cellulase activity were pooled and dialyzed against $10 \mathrm{mM}$ sodium phosphate buffer ( $\mathrm{pH}$ 7.0) and lyophilized. The dried material was dissolved in $0.05 \mathrm{M} \mathrm{NaCl}-10 \mathrm{mM}$ sodium phosphate buffer ( $\mathrm{pH} 6.0$ ) and subjected to AKTA-FPLC (GE Healthcare) equipped by Superdex 200 10/300 GL column. Cellulase was eluted with $0.05 \mathrm{M} \mathrm{NaCl}-$ $10 \mathrm{mM}$ sodium phosphate buffer $(\mathrm{pH}$ 6.0) at a flow rate of $1 \mathrm{~mL} / \mathrm{min}$.

\section{ASSAY FOR CELLULASE ACTIVITY}

Standard assay for cellulase activity was carried out with a reaction mixture containing $0.5 \% \mathrm{CMC}, 10 \mathrm{mM}$ sodium phosphate (pH 6.0), and $0.01-0.1 \mathrm{mg} / \mathrm{mL}$ of enzyme at $30^{\circ} \mathrm{C}$. Reducing sugar released by the reaction was determined by the method of Park and Johnson (1949). One unit of cellulase activity was defined as the amount of enzyme that produces reducing sugar equivalent to $1 \mu \mathrm{mol}$ of glucose per $1 \mathrm{~min}$. Temperature dependence of the cellulase was determined at $10-70^{\circ} \mathrm{C}$ and $\mathrm{pH}$ 6.0. $\mathrm{pH}$ dependence was determined at $30^{\circ} \mathrm{C}$ in reaction mixtures adjusted to pH 4.0-10.0 with $50 \mathrm{mM}$ sodium phosphate. Thermal stability was assessed by measuring the residual activity in the standard assay condition after heating at $10-70^{\circ} \mathrm{C}$ for $30 \mathrm{~min}$. The average values of triplicate measurements were shown with standard deviations.

\section{THIN-LAYER CHROMATOGRAPHY}

Thin-layer chromatography (TLC) for degradation products of cellulose and cellooligosaccharides was carried out with Silica gel-60 TLC plates (Merck KGaA, Darmstadt, Germany). Two $\mu \mathrm{L}$ of the degradation products $(\sim 5 \mathrm{mg} / \mathrm{mL})$ were applied to the TLC plate and developed with 1-butanol/acetic acid/water (2:1:1, $\mathrm{v} / \mathrm{v} / \mathrm{v})$. The sugars separated on the plate were detected by heating at $120^{\circ} \mathrm{C}$ for $15 \mathrm{~min}$ after spraying $10 \%(\mathrm{v} / \mathrm{v})$ sulfuric acid in ethanol.

\section{SDS-PAGE}

SDS-PAGE was carried out by the method of Porzio and Pearson (1977) using 10\% (w/v) polyacrylamide gel containing $0.1 \%$ (w/v) SDS. After the electrophoresis, the gel was stained with $0.1 \%(\mathrm{w} / \mathrm{v})$ Coomassie Brilliant Blue R-250-50\% (v/v) methanol$10 \%(\mathrm{v} / \mathrm{v})$ acetic acid, and the background of the gel was destained with $5 \%(\mathrm{v} / \mathrm{v})$ methanol-7\% (v/v) acetic acid. Molecular masses of proteins were estimated with a Protein Marker, Broad Range (New England Biolabs, Inc. MA, USA).

\section{PROTEIN CONCENTRATION}

Protein concentration was determined by either the biuret method (Gornall et al., 1949) or the method of Lowry et al. (1951) using bovine serum albumin fraction $\mathrm{V}$ as a standard protein.

\section{DETERMINATION OF PARTIAL AMINO-ACID SEQUENCES}

The N-terminal amino-acid sequence of cellulase was determined with specimens electro-blotted to polyvinylidene difluoride membrane and ABI 492 protein sequencer (Applied Biosystems). The internal amino-acid sequences of cellulase were determined by mass spectrometry with tryptic and lysylendopeptidyl fragments prepared by the digestion with $1 / 200(\mathrm{w} / \mathrm{w})$ enzymes at $37^{\circ} \mathrm{C}$ for $12 \mathrm{~h}$. The fragments were subjected to matrix-assisted laser desorption ionization-time of flight mass spectrometry (MALDI-TOF MS) using Proteomics Analyzer 4700 (Applied Biosystems) and the amino-acid sequences of the fragments were analyzed by MS/MS mode with DeNovo Explorer software (Applied Biosystems). Homology searches for the amino-acid sequences to the public databases were performed with the BLAST program (http://blast.ddbj.nig.ac.jp/top-j.html) provided by DNA Data Bank of Japan.

\section{cDNA CLONING}

Total RNA was extracted from $\sim 0.1 \mathrm{~g}$ of hepatopancreas of A. kurodai using RNAiso Plus and mRNA was selected from the total RNA with Oligotex-dt(30) (TaKaRa). Hepatopancreas cDNA was synthesized from the mRNA with a cDNA synthesis kit (TaKaRa) using random hexanucleotide primers. Cellulase cDNAs were amplified by the PCR using the hepatopancreas cDNA and degenerated primers synthesized on the basis of partial amino-acid sequences. PCR was performed in $20 \mu \mathrm{L}$ of reaction mixture containing $50 \mathrm{mM} \mathrm{KCl}, 15 \mathrm{mM}$ Tris- $\mathrm{HCl}(\mathrm{pH}$ 8.0), $0.2 \mathrm{mM}$ each of dATP, dTTP, dGTP, and dCTP, $2.5 \mathrm{mM}$ $\mathrm{MgCl}_{2}, 5 \mathrm{pmol} / \mu \mathrm{L}$ primers, $1 \mathrm{ng} / \mu \mathrm{L}$ template DNA, and 0.5 units AmpliTaq Gold DNA polymerase (Applied Biosystems). A successive reaction consisting of $94^{\circ} \mathrm{C}$ for $30 \mathrm{~s}, 55^{\circ} \mathrm{C}$ for $30 \mathrm{~s}$, and $72^{\circ} \mathrm{C}$ for $60 \mathrm{~s}$ was repeated 40 cycles with Thermal Cycler Dice mini (TaKaRa). Sizes of amplified cDNAs were estimated by $1.2 \%$ agarose-gel electrophoresis and the target cDNAs were excised from the gel and cloned with TA-PCR cloning kit (Invitrogen). 
The transformed E. coli was grown in $2 \times$ YT medium supplemented by $50 \mu \mathrm{g} / \mathrm{mL}$ ampicillin at $37^{\circ} \mathrm{C}$ for $14 \mathrm{~h}$ with shaking at $150 \mathrm{rpm} / \mathrm{min}$. The plasmids extracted from the transformants were subjected to sequence analysis with BigDye-Terminator Cycle Sequencing kit and ABI 3130xl Genetic Analyzer (Applied Biosystems). The $3^{\prime}$-RACE and 5'-RACE PCRs were carried out with specific primers synthesized on the basis of nucleotide sequences of above amplified cDNAs with a successive reaction at $94^{\circ} \mathrm{C}$ for $30 \mathrm{~s}, 57^{\circ} \mathrm{C}$ for $30 \mathrm{~s}$, and $72^{\circ} \mathrm{C}$ for $1.0 \mathrm{~min}$, which was repeated 30 cycles. The amplified DNAs were cloned and sequenced as described above.

\section{PHYLOGENETIC ANALYSIS FOR GHF45 CELLULASES}

Phylogenetic analysis was carried out with amino-acid sequence data of A. kurodai cellulase and other GHF45 cellulases which are enrolled in GenBank (http://www.ncbi.nlm.nih.gov/) and CAZy database (http://www.cazy.org/fam/acc_GH.html). The aminoacid sequences of GHF45 cellulases were first aligned with ClustalW2 program (Larkin et al., 2007). The alignment was then corrected by trimming the sequences with Gblocks (Castresana, 2000; Talavera and Castresana, 2007). The maximum-likelihood algorithm implemented in MEGA6 software (Tamura et al., 2013) was used to generate phylogenetic tree. The bootstrap values were calculated from 1,000 replicates.

\section{RESULTS}

\section{ISOLATION AND CHARACTERIZATION OF APLYSIA 21 kDa CELLULASE}

Cellulase activity was detected in four peak fractions $(P-1-P-4)$ in TOYOPEARL CM-650M chromatography performed for the proteins obtained by the ammonium sulfate fractionation (Figure 1). The N-terminal amino-acid sequences of major proteins in $P-1-P-4$ fractions were analyzed with the samples blotted to PVDF membranes after SDS-PAGE. According to BLAST search analyses, the $40 \mathrm{kDa}$ protein in $P-1$ fraction (N-terminal sequence: RLHIQNGHFVLNGQRVFLSG) was identified as $A$. kurodai $\beta$-mannanase AkMan (Zahura et al., 2010). The $21 \mathrm{kDa}$ protein in $P$-2 fraction (N-terminal sequence: EQKCQPNSHGVRVYQGKKCA) was considered to be a GHF45 cellulase corresponding to $21 \mathrm{~K}$ cellulase previously reported by Tsuji et al. (2013). The $45 \mathrm{kDa}$ protein in P-4 fraction (N-terminal sequence: AKNYGQALGLSIKFYEAQ) was regarded as a GHF9 cellulase similar to $H$. discus hannai HdEG66 (Suzuki et al., 2003) and $45 \mathrm{~K}$ cellulase reported by Tsuji et al. (2013). While $38 \mathrm{kDa}$ protein (N-terminal sequence: RLTVSGKTFRLNNQQVFLSG) was regarded as the $\beta$-mannanase-like protein that had been annotated in A. california genome (GenBank accession number, XP_005100017). The $21 \mathrm{kDa}$ cellulase in $P$-2 fraction was recovered in high yield, while the GHF9-type cellulase in $P-4$ fraction poorly recovered. The GHF9-type cellulase exhibited similar properties as abalone cellulase HdEG66 (Suzuki et al., 2003) and Aplysia 66K cellulase (Tsuji et al., 2013). Therefore, in the present study, we focused on the $21 \mathrm{kDa}$ cellulase in $P$ - 2 fraction to characterize it as a GHF45 cellulase.

The $21 \mathrm{kDa}$ cellulase in $P-2$ fraction was purified by gelfiltration through Superdex 200 (Figure 2). In this chromatography, the $21 \mathrm{kDa}$ cellulase eluted as a single peak showing a single band on SDS-PAGE. Thus, we named this enzyme AkEG21
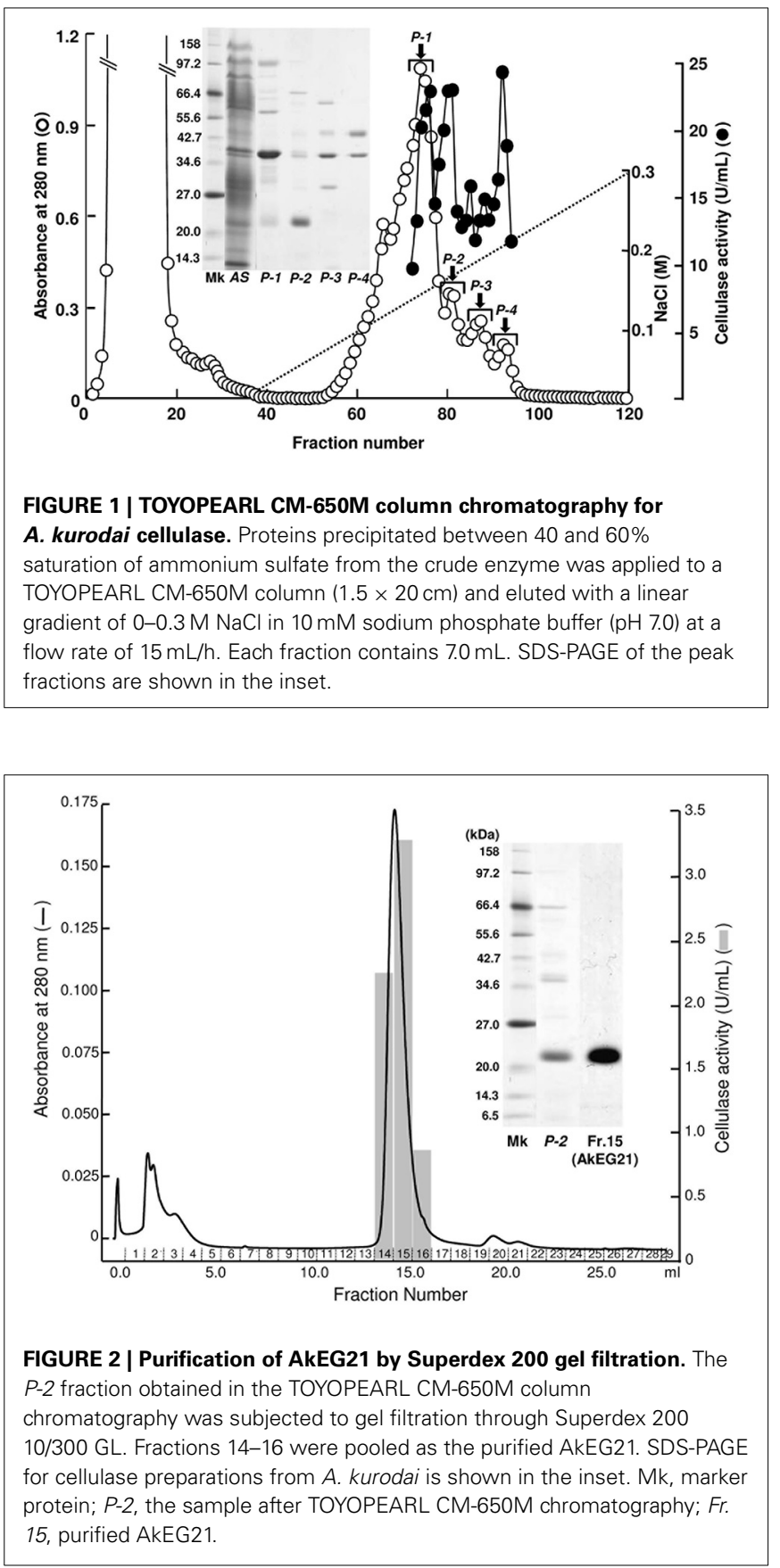

(Aplysia kurodai endo- $\beta$-1,4-glucanase with $21 \mathrm{kDa}$ ). By the above purification procedure, AkEG21 was purified at a yield of $3.3 \%$ with the specific activity $67.3 \mathrm{U} / \mathrm{mg}$ (Table 1 ). Optimal $\mathrm{pH}$ of AkEG21 was 4.5 and more than $80 \%$ of maximal activity was retained in a $\mathrm{pH}$ range from 4.3 to 5.6 (Figure 3A). AkEG21 showed an optimal temperature at around $40^{\circ} \mathrm{C}$ and it was resistant to the incubation at $55^{\circ} \mathrm{C}$ for $30 \mathrm{~min}$. The temperature that caused a half inactivation of AkEG21 during $30 \mathrm{~min}$ incubation was $\sim 65^{\circ} \mathrm{C}$ (Figures 3B,C). These results indicated that AkEG21 was relatively heat-stable among the molluscan cellulases reported so far. 
Table 1 | Summary of purification of AkEG21.

\begin{tabular}{|c|c|c|c|c|c|}
\hline Purification & Total protein (mg) & Total activity (U) & Specific activity (U⿳亠丷⿵冂⿱十口) & Purification (fold) & Yield (\%) \\
\hline$A S^{c}$ & 798 & 8912 & 11.2 & 1.4 & 77.2 \\
\hline Gel filtration ${ }^{e}$ & 5.6 & 376.1 & 67.3 & 8.4 & 3.3 \\
\hline
\end{tabular}

${ }^{a}$ One unit $(U)$ of cellulase was defined as the amount of enzyme that produces reducing sugar equivalent to $1 \mu \mathrm{mol}$ of glucose per minute from $0.5 \%$ CMC.

${ }^{b}$ Crude enzyme after the dialysis against $2 \mathrm{mM}$ sodium phosphate buffer ( $\mathrm{pH}$ 7.0).

${ }^{c}$ Fraction precipitated between 40 and $60 \%$ saturation of ammonium sulfate.

${ }^{a}$ Active fraction obtained by TOYOPEARL CM-650M chromatography.

eAkEG21 purified by the gel filtration through Superdex 200 10/300 GL.
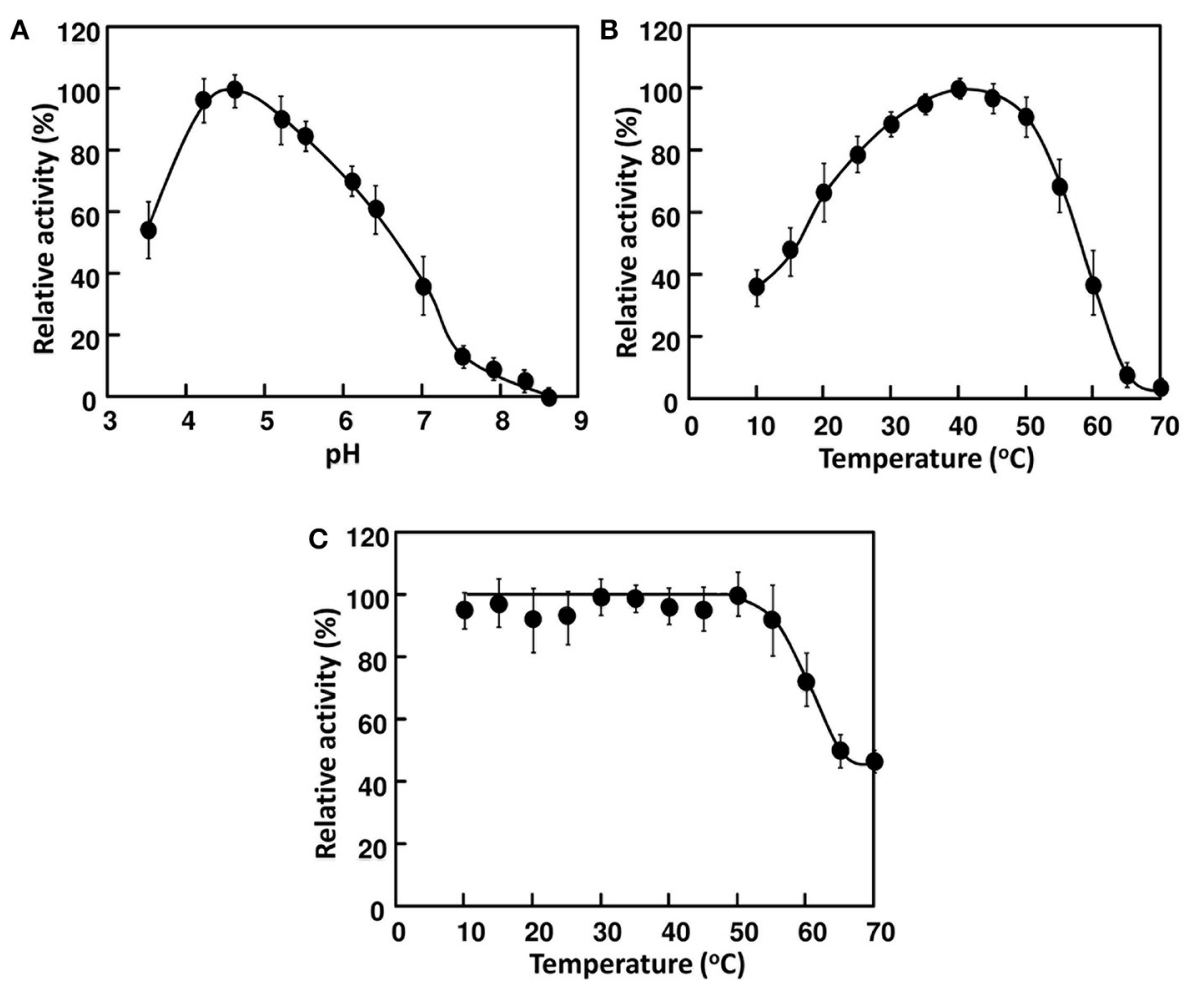

FIGURE 3 | Effects of $\mathrm{pH}$ and temperature on the activity of AkEG21. (A) $\mathrm{pH}$ dependence of $A k E G 21$ was examined at $30^{\circ} \mathrm{C}$ using reaction mixtures adjusted to $\mathrm{pH} 4-10$ with $50 \mathrm{mM}$ sodium phosphate buffer. (B) Temperature dependent activity of AkEG21 was measured at $10-60^{\circ} \mathrm{C}$ in a reaction mixture containing $0.5 \% \mathrm{CMC}$ and $10 \mathrm{mM}$ sodium phosphate $(\mathrm{pH}$ 6.0). (C) Thermal stability of AkEG21 was assessed by measuring the activity remaining after the heat-treatment at $10-70^{\circ} \mathrm{C}$ for $30 \mathrm{~min}$.
Degradation products of cellulose and cellooligosaccharides produced by AkEG21 were analyzed by TLC. As shown in Figure 4A, AkEG21 degraded amorphous cellulose producing cellobiose and cellotriose. Cellooligosaccharides larger than cellotriose were not detected in the reaction products even after $16 \mathrm{~h}$ incubation. On the other hand, AkEG21 showed high activity toward hexaose (G6) and pentaose (G5) and weak activity toward tetraose (G4), but no activity toward triose (G3) (Figure 4B). AkEG21 readily degraded G5 to G2 and G3 (plus trace amount of G4 and glucose), and degraded G6 to G2 and G4 along with small amount of G3. These degradation profiles were practically unchanged even in the longer reaction time and higher enzyme concentrations although the amounts of the products were increased (data not shown). These results indicate that AkEG21 is an endo- $\beta$-1,4-D-glucanase (EC 3.2.1.4). However, readily production of cellobiose and small amount of cellotriose from amorphous cellulose without larger intermediate oligosaccharides may indicate that this enzyme can act as cellobiohydrolase-like enzyme as suggested by Tsuji et al. (2013).

\section{CLONING OF AkEG21 cDNA}

The N-terminal amino-acid sequence of AkEG21 was determined as EQKCQPNSHGVRVYQGKKCA- by the protein sequencer (Table 2). This sequence shared $\sim 40,40,55$, and $60 \%$ amino-acid 


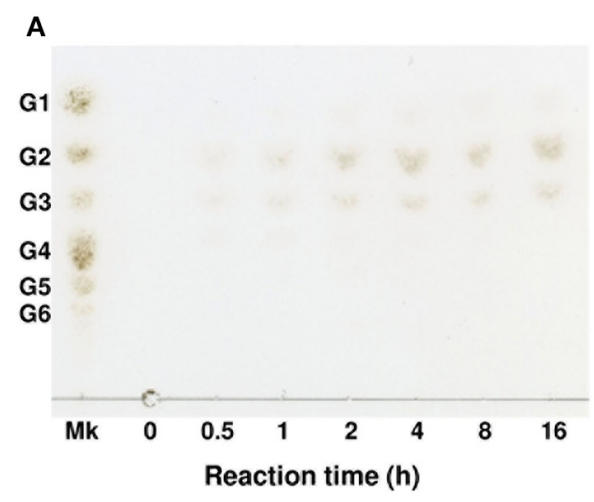

FIGURE 4 | Thin-layer chromatography of degradation products of phosphoric acid-swollen cellulose and cello-oligosaccharides produced by AkEG21. (A) The reaction mixture of $1.0 \mathrm{~mL}$ containing $2.5 \mathrm{mg}$ of phosphoric acid-swollen cellulose, $10 \mathrm{mM}$ sodium phosphate $(\mathrm{pH} 6.0)$, and 7 $\mathrm{U}$ of AkEG21 was incubated at $37^{\circ} \mathrm{C}$ for up to $16 \mathrm{~h}$. The supernatant of the

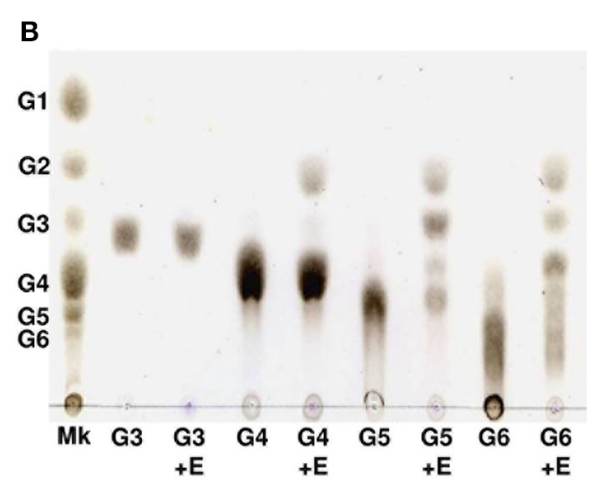

reaction mixture was subjected to TLC. (B) The reaction mixture of $0.05 \mathrm{~mL}$ containing $0.05 \mathrm{mg}$ of G3-G6, $10 \mathrm{mM}$ sodium phosphate ( $\mathrm{pH} 6.0)$, and $7 \mathrm{U}$ of AkEG21 was incubated at $30^{\circ} \mathrm{C}$ for $24 \mathrm{~h}$, then subjected to TLC. G1, glucose; G2, cellobiose; G3, cellotriose; G4, cellotetraose; G5, cellopentaose; G6, cellohexaose. Mk, marker sugars.
Table 2 | N-terminal and internal amino-acid sequences of AkEG21.

\begin{tabular}{|c|c|c|}
\hline Peptides $^{a}$ & Amino-acid sequences & $\begin{array}{l}\text { Similarity }(\%) \text { to other molluscan } \\
\text { GHF45 enzymes }{ }^{\text {b }}\end{array}$ \\
\hline AkEG21 & EQKCQPNSHGVRVYQGKKCA- & $\begin{array}{l}\text { A. crossean }(60.0 \%, 17-36) \\
\text { H. discus discus }(55.0 \%, 18-36)\end{array}$ \\
\hline $\mathrm{L}-1$ & VNDHGYEAHFDLQNNK & $\begin{array}{l}\text { A. crossean }(68.8 \%, 143-158) \\
\text { H. discus discus }(68.8 \%, 141-156)\end{array}$ \\
\hline $\mathrm{L}-2$ & LTPTGGFVPGNGK & $\begin{array}{l}\text { A. crossean }(84.6 \%, 95-107) \\
\text { H. discus discus }(61.5 \%, 92-104)\end{array}$ \\
\hline $\mathrm{T}-1$ & COPNSHGVR & $\begin{array}{l}\text { A. crossean }(77.8 \%, 20-28) \\
\text { H. discus discus }(44.4 \%, 21-28)\end{array}$ \\
\hline $\mathrm{T}-2$ & WWCGQSGKPGTNK & $\begin{array}{l}\text { A. crossean }(61.5 \%, 130-142) \\
\text { H. discus discus }(46.2 \%, 128-140)\end{array}$ \\
\hline $\mathrm{T}-3$ & YNDGHR & $\begin{array}{l}\text { A. crossean }(66.7 \%, 41-46) \\
\text { H. discus discus }(83.3 \%, 41-46)\end{array}$ \\
\hline
\end{tabular}

${ }^{a}$ L-1 and L-2, Lysylendopeptidyl fragments; T-1-T-3, tryptic fragments.

${ }^{b}$ Residue numbers for corresponding regions in the sequences of $A$. crossean and $H$. discus discus (see Figure 6) are also shown in the parentheses.

identities to those of Eg from M. edulis (DDBJ accession number, CAC59694), CjCel45A from C. japonica (DDBJ accession number, AB468959), endo- $\beta$-1,4-glucanase 1 from $H$. discus discus (DDBJ accession number, EF103350) and EG27I from A. crossean (DDBJ accession number, EF471315), respectively. The sequences of tryptic and lysylendopeptidyl fragments of AkEG21 also showed $62-85 \%$ identities with the corresponding sequences of above molluscan cellulases (Table 2). Such high sequence similarities of partial amino-acid sequences between AkEG21 and other GHF45 cellulases suggested that AkEG21 also belongs to GHF45.

To determine the entire amino-acid sequence of AkEG21, we amplified AkEG21 cDNA by the PCR using degenerated forward and reverse primers, $c D N A-1(\mathrm{Fw})$ and $\mathrm{cDNA}-1(\mathrm{Rv})$, respectively (Table 3). The amplified cDNA comprised $405 \mathrm{bp}$ and encoded an amino-acid sequence of 135 residues. Then, 3RACE-cDNA of 519 bp covering the $3^{\prime}$-terminal region was amplified by $3^{\prime}$-RACE PCR with specific primers designed on the basis of the nucleotide
Table 3 | Primers used for amplification of AkEG21-cDNA.

\begin{tabular}{|c|c|}
\hline Primer names & Sequences \\
\hline \multicolumn{2}{|l|}{ PCR } \\
\hline cDNA-1 (Fw) & $\begin{array}{l}\text { 5'-AARACNCARCCNAAYWSNCAYGGNGTNMGNATG-3'a } \\
\text { (KTQPNCHGVRM) }^{\text {b }}\end{array}$ \\
\hline cDNA-1(Rv) & $\begin{array}{l}\text { 5'-TCRAARTGNGCYTCRTANCCRTGRTC-3' } \\
\text { (DHGYEAHFD) }\end{array}$ \\
\hline \multicolumn{2}{|l|}{ 3'-RACE } \\
\hline $3 \mathrm{Fw}$ & 5'-TGACCAATAGCTGCCCTATC-3' \\
\hline 3Adapt & 5'-CTGATCTAGAGGTACCGGATCC-3' \\
\hline \multicolumn{2}{|l|}{ 5'-RACE } \\
\hline 5RACE(Fw2) & 5'-TGGATTCGTTCCTGGCAACG-3' \\
\hline 5RACE(Rv2) & 5'-GTTTGGACATGTTCCAGTCG-3' \\
\hline \multicolumn{2}{|c|}{ CONFIRMATION } \\
\hline 5FullFw & 5'-ATCTCAGATCTAGAGAACCC-3' \\
\hline 3FullRv & 5'-CGCAAATCTCACGAAAATCGCG-3' \\
\hline
\end{tabular}

${ }^{a} R$, adenine or guanine; $Y$, cytosine or thymine; $W$, adenine or thymine; $S$, cytosine or guanine; $M$, adenine or cytosine; $N$, adenine or guanine or cytosine or thymine.

${ }^{b}$ Amino-acid sequences used for designing the degenerated primers are in the parentheses.

sequence of the first amplified cDNA. Finally, 5RACE-cDNA of 363 bp covering $5^{\prime}$-terminal region was amplified by $5^{\prime}$-RACE PCR with a series of specific primers synthesized on the basis of the sequence of the amplified cDNA. By overlapping the nucleotide sequences of 5RACE-cDNA, first amplified CDNA and 3RACE-cDNA in this order, the nucleotide sequence of total $1013 \mathrm{bp}$ including the complete translational region of AkEG21 was determined (Figure 5). The transcription-initiation codon (ATG) was found in the nucleotide positions from 162 to 164, while the termination codon (TGA) was in 753-755. Accordingly, the coding region of AkEG21 cDNA was found to locate in the nucleotide positions from 162 to 752 and encode 197 aminoacids. All the partial amino-acid sequences determined with 


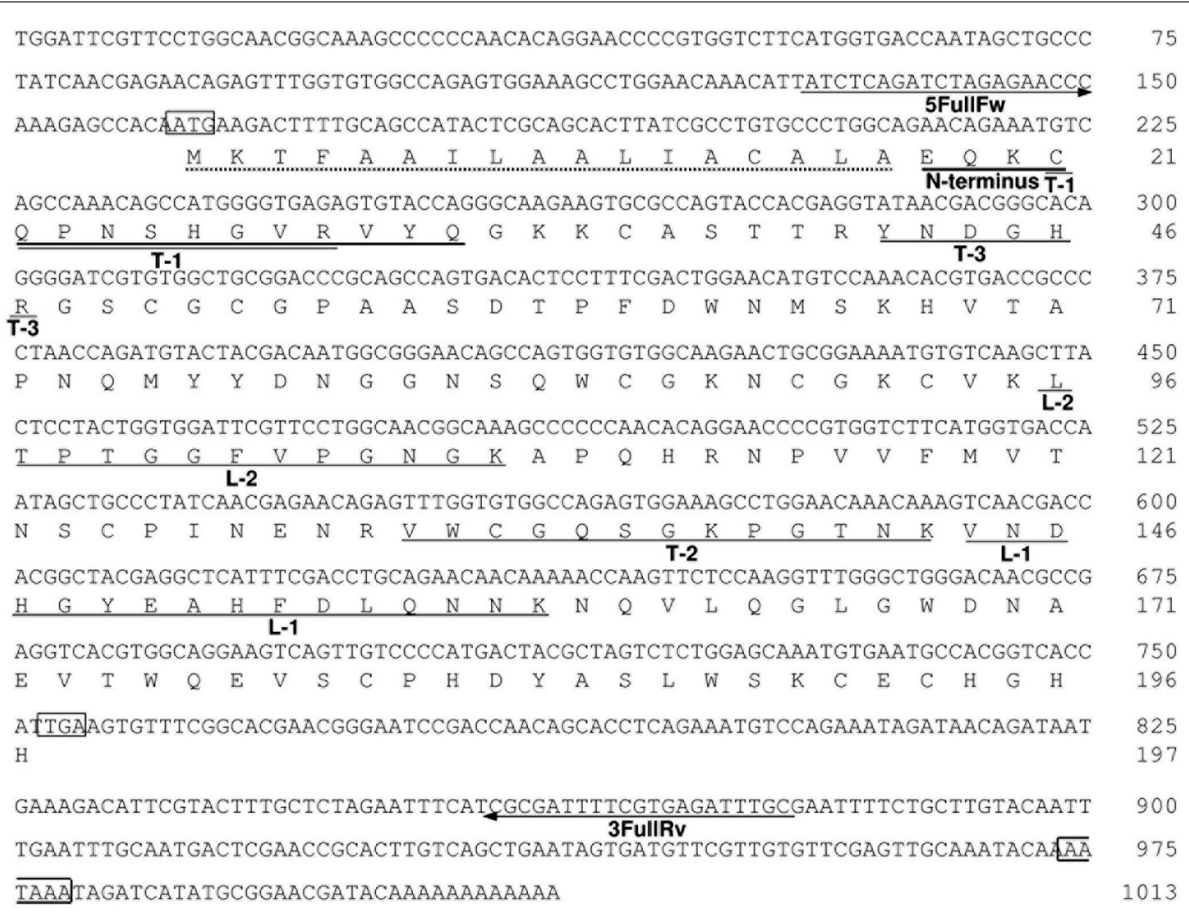

FIGURE 5 | The nucleotide and deduced amino-acid sequences of AkEG21. Residue numbers for nucleotides and amino-acids are indicated in the right of each row. The translational initiation codon ATG, termination codon TGA, and a putative polyadenylation signal AATAAA are boxed. A putative signal peptide is indicated by a dotted underline. The amino-acid sequences determined with intact AKEG21 ( $\mathrm{N}$-terminus) and peptide fragments (L-1, L2, T1-T-3) are indicated with solid lines under the amino-acid sequence. The positions of 5FullFw and 3FullRv primers are indicated with arrows under the nucleotide sequence. The sequence data are available from the DNA Data Bank of Japan with an accession number, AB920344. peptide fragments, L-1, L-2, and T-1-T-3 (Table 2), were found in the deduced sequence (Figure 5). A putative polyadenylationsignal sequence (AATAAA) located at 22 nucleotides upstream from the poly $(\mathrm{A})^{+}$tail. This suggested that the origin of AkEG21cDNA was not intestinal prokaryotes but eukaryote, i.e., Aplysia itself. The N-terminus of mature AkEG21 protein was identified as Glu18 in the deduced sequence indicating that the $\mathrm{N}$-terminal region of 16 residues except for initiation Met was the signal peptide for secretion. Indeed, KTFAAILAALIACALA located in the $\mathrm{N}$-terminus of the deduced sequence was predicted as the signal peptide by SignalP 4.1 server (http://www. cbs.dtu.dk/services/SignalP/). Accordingly, the mature AkEG21 was concluded to comprise 180 amino-acid residues with the calculated molecular mass of 19,854.0 Da (Figure 5). The nucleotide and the deduced amino-acid sequences are available from the DNA Data Bank of Japan with the accession number AB920344.

The amino-acid sequence of AkEG21 was aligned with those of other molluscan GHF45 cellulases (Figure 6) and $47,49,54$, and $62 \%$ identities were calculated between AkEG21 and Eg from M. edulis (GenBank accession number, CAC59695), CjCel45A from C. japonica (GenBank accession number, BAH23793), endo- $\beta$-1,4-glucanase 1 from $H$. discus discus (GenBank accession number, ABO26608), and EG27I from A. crossean (GenBank accession number, ABR92637), respectively. The consensus amino-acid sequence T-T-R-Y-X-D that has been shown to take part in the catalytic site of GHF45 enzymes (Girard and Jouanin, 1999; Guo et al., 2008) was conserved in AkEG21 as Thr39-Asp44. The N-glycosylation site (Asn-X-Thr/Ser) was also conserved as Asn64-Ser66 where Ans64 was the $\mathrm{N}$-glycosylation residue according to the analyses with NetNGlyc 1.0 server (http://www.cbs.dtu.dk/services/ NetNGlyc/). Twelve Cys residues that form six disulfide bonds stabilizing the catalytic domain were also conserved in AkEG21. Two Asp residues that function as catalytic nucleophile and proton donor in GHF45 enzymes were conserved as Asp44 and Asp154, respectively, in AkEG21. These features in the aminoacid sequence of AkEG21 indicate that this enzyme belongs to GHF45.

\section{PHYLOGENETIC ANALYSIS}

To reveal the structural relationship between AkEG21 and other GHF45 cellulases, phylogenetic analysis was performed using amino-acid sequence data of GHF45 cellulases from mollusk, fungi, insects, nematode, protists and bacteria. The tree topology drawn by the maximum likelihood analysis revealed that molluscan GHF45 cellulases are assembled as a large clade (bootstrap values above 50\%) with some fungal enzymes (Figure 7). Whereas, enzymes from insects, nematode, protists, bacteria and some other fungi formed another paraphyletic group. These clustering results suggest that molluscan GHF45 cellulases have been deviated from other animal cellulases but closely related to some fungal cellulases. 


\begin{tabular}{|c|c|c|c|c|c|c|c|}
\hline Aplysia & MKTFAAIL & AALIACALAE & QKCQPNSHGV & RVYQGKKCAS & TTRYNDGHRG & SCGCGPAASD & 58 \\
\hline Mytilus & MKYLVLSL & LVLVYSVSAN & QKCSGNP--- & RRYNGKSCAS & TTNYHDSHKG & ACGCGPASGD & 55 \\
\hline Corbicula & MKVAAAVLLA & LVGLVCVDAN & QKCSGNP--- & LSYQGKRCAS & TTWYADYHKG & ACGCGPDNND & 57 \\
\hline Haliotis & MKTAVSIL & LLFAASAWAN & QKCQMHNG-I & RMYNGKHCAS & TTRYNDGHKG & ACGCG--QND & 55 \\
\hline \multirow[t]{2}{*}{ Ampullaria } & MKLFYLL & CLAVPLLEAA & QLCQPDSRGV & RRFNGKPCAS & TTRYVDGHKG & ACGCGQKGSD & 57 \\
\hline & & * & $\star * .$. & $:: * \star * \star \star$ & $\star \star \star \star \star *: *$ & $: \star \star \star \star$ & \\
\hline Aplysia & TPFDWNMSKH & VTAPNQMYYD & NGGNSQWCGK & NCGKCVKLTP & TGGFVPGNGK & APQHRNPVVF & 118 \\
\hline Mytilus & AQFGWNAGSF & VAAASQMYFD & SGNKG-WCGQ & HCGQCIKLTT & TGGYVPGQGG & PVREGLSKTF & 114 \\
\hline Corbicula & NQFDWNHSKF & VAAASQHLFD & PGLKT-WCGA & QCGKCVKLTT & TGGFVDGQGS & HVAEGQSHVF & 116 \\
\hline Haliotis & TPFPWNNNQY & VAAANQKLFS & NSGST-WCGD & SCGKCVKLTT & TGGSIPGAGT & GAHAGQSHVF & 114 \\
\hline \multirow[t]{2}{*}{ Ampullaria } & TPFPWNIQKH & VTAPSERYFD & GGGSSLWCGR & NCGKCVKLTP & TGGFVPGKGN & APPNHNPVVF & 117 \\
\hline & $\star * * \quad \ldots$ & ${ }^{\star}:{ }^{\star} \ldots: \quad:$ & . . ${ }^{* \star *}$ & $\star \star *:^{*}: * * \star$ & $\star \star \star: * \star$ & & \\
\hline$A p$ & MVTNSCP-IN & ENRVWCGQSG & KPGTNKVNDH & GYEAHFDLQN & NKNQVLQGLG & WD--NAEVTW & .75 \\
\hline Mytilus & MITNLCPNIY & PNQDWCNQG- & -SQYGGHNKY & GYELHLDLEN & GRS-QVTGMG & WN--NPETTW & 169 \\
\hline Corbicula & MITNLCPNEW & PNLSWCSQS- & -SQSGYKNHY & GYSEHFDLED & GAG-QVAAIG & WKGKNPEVTW & 173 \\
\hline Haliotis & MITNDCPDVA & PNLEWCAQKG & APGSGHGNTH & GYEVHFDLEN & NGN-QISKLG & WD--NPEVTW & 171 \\
\hline \multirow[t]{2}{*}{ Ampullaria } & QVTNACP-IN & GNEEWCGISG & APGTGHVNSH & GYEVHFDLQD & QVG-QVEALH & WD--NPEVTW & 173 \\
\hline & $: \star \star \star \star$ & & . $\quad \star \quad:$ & ${ }^{\star \star} .{ }^{\star}:{ }^{\star \star}::$ & . : : & & \\
\hline Aplysia & DYA & $S---------$ & LWSKCECHGH & $\mathrm{H}$ & & & 197 \\
\hline Mytilus & EVVNCDSEHN & HDHRTP-SNS & MYGQCQCAHQ & GKRGLNETSN & ESL & & 211 \\
\hline Corbicula & EYVNCDQAHS & ADSRTPGTRT & EYSQCFCSKH & PDGGK & & & 208 \\
\hline Haliotis & EWSSCHGSN- & $-----\mathrm{TPTDQ}$ & MWHTCECSH & & & & 194 \\
\hline Ampullaria & $\underset{*}{\operatorname{EETSCPGDLQ}}$ & $\mathrm{S}---------$ & $\underset{\star{ }_{\star}}{\text { NYQQCECHNS }}$ & G & & & 195 \\
\hline
\end{tabular}

FIGURE 6 | Alignment of the amino-acid sequences of AkEG21 and other molluscan GHF45 cellulases. The amino-acid sequence of AkEG21 (DDBJ accession number, AB920344) was aligned with those of endoglucanase $(\mathrm{Eg})$ from $M$. edulis (DDBJ accession number, CAC59694), CjCel45A from C. japonica (DDBJ accession number, AB468959), endo- $\beta-1,4-$ glucanase 1 from H. discus discus (DDBJ accession number, EF103350), and EG27I from
A. crossean (DDBJ accession number, EF471315). Identical, highly conservative, and conservative residues among sequences are indicated by asterisk (*), colon (:), dot (.), respectively. The consensus amino-acid sequence and residues in catalytic sites of GHF45 cellulases are boxed and shaded, respectively. The putative $\mathrm{N}$-glycosylation site is underlined and $\mathrm{N}$-glycosylated residue is indicated with bold letter.

\section{DISCUSSION}

The ocean that covers $70 \%$ of surface on the Earth is rich in biodiversity, e.g., organisms from 34 of 38 animal phyla are living in the ocean. Through the adaptation to diverse physical and chemical conditions of marine environments, marine organisms are believed to have deviated along with acquiring specific phenotypes. Thus, the marine organisms have become capable of producing variety of characteristic chemical compounds relating to lipids, proteins and carbohydrates, as a result of adaptation to marine environments. Such marine bio-products are promising materials for functional food additives, pharmaceutics, cosmetics, industrial materials, energy sources, etc. Among the marine bio-products, polysaccharides produced by marine algae, e.g., agar, carrageenan and alginate, which have already been used as gelling agents, viscosifiers and dietary fibers in food, are also important materials for producing functional oligosaccharides and fermentable sugars (Nishida et al., 2007; Kumagai and Ojima, 2009; Rahman et al., 2010; Zahura et al., 2010; Takeda et al., 2011; Wargacki et al., 2012; Tsuji et al., 2013; Yanagisawa et al., 2013; Enquist-Newman et al., 2014; Kumagai et al., 2014). Actually, enzymatically degraded seaweed polysaccharides were shown to exhibit beneficial activities to human (Deville et al., 2007; Wang et al., 2012; Thomas and Kim, 2013). Further, monosaccharides produced by the degradation of alginate were found to be available as a source material for ethanol fermentation (Takeda et al., 2011; Wargacki et al., 2012; Enquist-Newman et al., 2014). While, sea lettuce Ulva pertusa was also used as feedstock for acetone and ethanol (Yanagisawa et al., 2011; van der Wal et al., 2012). These trends have stimulated the exploration of new enzymes that convert seaweeds' polysaccharides to value-added materials.
Herbivorous mollusks produce various kinds of polysaccharide-degrading enzymes, e.g., alginate lyase (Wong et al., 2000; Shimizu et al., 2003; Suzuki et al., 2006; Rahman et al., 2010), mannanase (Zahura et al., 2010, 2011), laminarinase (Kozhemyako et al., 2004; Kovalchuk et al., 2006, 2009; Kumagai and Ojima, 2009, 2010; Pauchet et al., 2009), amylase (Kumagai et al., 2012) and cellulase (Suzuki et al., 2003; Guo et al., 2008; Sakamoto and Toyohara, 2009). Among these enzymes, cellulase appears to be most widely distributed in mollusks (Elyakova, 1972; Nishida et al., 2007; Sakamoto and Toyohara, 2009; Ravindran et al., 2010; Nagano et al., 2011). However, information about enzymatic properties and physiological significance of molluscan cellulases are still poorly understood compared with the enzymes from microbes (Tomme et al., 1995; Hong et al., 2002; Masuda et al., 2006; Fibriansah et al., 2007). In the present study, we isolated a GHF45-type cellulase AkEG21 from the common sea hare A. kurodai and determined its general properties.

AkEG21 showed an optimum $\mathrm{pH}$ at around 4.5 and more than $80 \%$ of maximal activity retained at $\mathrm{pH}$ range from 4.3 to 5.6. This $\mathrm{pH}$ range is consistent with the $\mathrm{pH}$ range of the digestive fluid of A. kurodai, i.e., pH 4-6 (Zahura et al., 2011; Tsuji et al., 2013). Although optimal pH of microbial cellulases is known to vary from acidic to alkaline range (Hurst et al., 1977; Ito et al., 1989; Park et al., 2002), those of animal GHF45 cellulases are usually in acidic pH range. For example, optimal pHs of EG27 from A. crossean (Li et al., 2005) and Cel45A from M. edulis (Xu et al., 2000) were shown at around 4.4-4.8. While, heat stability of AkEG21 was found to be considerably high, i.e., it retained more than $80 \%$ of maximal activity after the pre-incubation at 


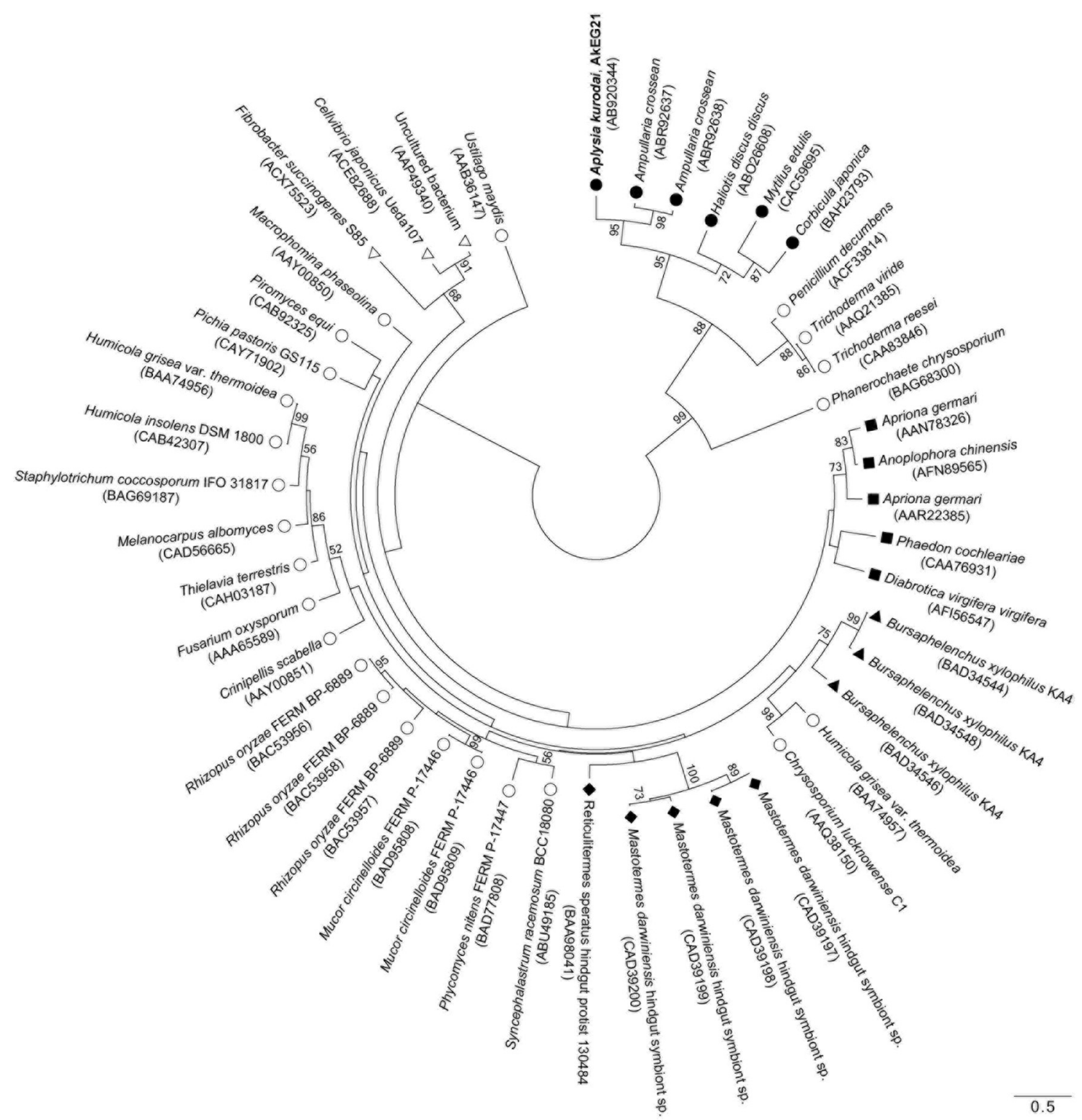

FIGURE 7 | Phylogenic relationship for GHF45 cellulases. An unrooted phylogenetic tree for catalytic domains of AkEG21 and GHF45 enzymes from CAZy database was generated using MEGA 6 software. Bootstrap values over 50 are indicated on the branches. The scale bar indicates 0.50 amino-acid substitutions. Symbols shown with scientific names of organisms indicate as follows: solid circles, mollusks; open circles, fungi; solid squares, insects; solid triangles, nematode; solid diamonds, protists; open triangles, bacteria. GenBank accession numbers for each sequence data are shown in the parentheses after the names of organisms. $55^{\circ} \mathrm{C}$ for $30 \mathrm{~min}$ and was not completely inactivated even at $70^{\circ} \mathrm{C}$ (Figure 3). Such high heat stability was also reported in EG27 from A. crossean (Li et al., 2005), Cel45A from M. edulis (Xu et al., 2000) and $21 \mathrm{~K}$ cellulase from A. kurodai (Tsuji et al., 2013). EG27 retained $\sim 85 \%$ of maximal activity after the incubation at $60^{\circ} \mathrm{C}$ for $24 \mathrm{~h}$ ( $\mathrm{Li}$ et al., 2005) and Cel45A retained more than $70 \%$ of the activity after the incubation in boiling water bath for $10 \mathrm{~min}$ (Xu et al., 2000). Such stabilities of GHF45 cellulases in acidic and high temperature conditions may be due to the formation of plural disulfide bonds in the catalytic domain. Such stability of GHF45 cellulase will be advantageous in performing both basic researches and biotechnological applications. On the other hand, M. edulis cellulase Cel45A was reported to show an unusual psychrophilic feature, i.e., it retains $55-60 \%$ of its maximum activity even at $0^{\circ} \mathrm{C}$ (Xu et al., 2000). AkEG21 also showed relatively high activity in low temperature conditions, e.g., it retained $\sim 40 \%$ of the maximal activity at $10^{\circ} \mathrm{C}$ (Figure 3 ). In this respect, molluscan GHF45 cellulases may be applicable for cellulose degradation in acidic and broad temperature conditions. 
AkEG21 produced cellotriose and cellobiose as major products from amorphous cellulose and efficiently hydrolyzed cellohexaose and cellopentaose, and moderately cellotetraose, but not cellotriose and cellobiose. These indicated that AkEG21 recognized cellotetraose unit in cellulose chain and split the central glycosyl linkage of tetraose. Such substrate-recognition profiles of AkEG21 were essentially the same as those of from Cel45A from M. edulis (Xu et al., 2000) and 21K cellulase from Aplysia (Tsuji et al., 2013).

By the cDNA method, an entire amino-acid sequence of AkEG21 comprising 197 residues was predicted. The sequence of catalytic domain comprising 180 residues shared $47-62 \%$ aminoacid identities with the other molluscan GHF45 cellulases and conserved T-T-R-Y-X-D motif and two Asp residues which were identified as catalytic site and residues of GHF45 enzymes (Girard and Jouanin, 1999; Bourne and Henrissat, 2001; Guo et al., 2008) (Figure 6). AkEG21 possessed a typical N-glycosylation motif (Asn-X-Thr/Ser) at amino-acid positions of 64-66, and the Ans64 was predicted to be the $\mathrm{N}$-glycosylation residue (Figure 6). The $21 \mathrm{~K}$ cellulase from Aplysia was shown to be glycosylated (Tsuji et al., 2013). This indicated that AkEG21 was a glycosylated enzyme. Cel45A from M. edulis (Xu et al., 2000) and CjCel45A from C. japonica (Sakamoto and Toyohara, 2009) were also suggested to be glysocylated at the N-glycosylation sites, while no N-glycosylation site was found in GHF45 cellulase from A. crossean (Guo et al., 2008) and H. discus discus (GenBank accession number, ABO26608) (Figure 6). On the other hand, coleopteran GHF45 cellulases, e.g., Ag-EGase I (contain 2 $\mathrm{N}$-glycosylation sites) and Ag-EGase II (contain $3 \mathrm{~N}$-glycosylation sites) from Apriona germari, and Oa-EGase II (contain $2 \mathrm{~N}$ glycosylation sites) from Oncideresalbomarginata chamela were found to be $\mathrm{N}$-glycosylated and the $\mathrm{N}$-glycosylations were important for secretion and enzyme activity (Wei et al., 2006; CalderonCortes et al., 2010). Previous report showed that $90 \%$ of proteins possessing the sequence Asn-X-Ser/Thr were glycosylated (Gavel and von Heijne, 1990). The roles of glycosylation are known to vary from protein to protein (Bisaria and Mishra, 1989; Wang and Gao, 2000). It is necessary to examine the physiological significance of the $\mathrm{N}$-glycosylation in AkEG21 using recombinant enzymes expressed in prokaryote cells where no glycosylation takes place.

AkEG21 contained 12 Cys residues. This suggested that occurrence of six disulfide bonds in AkEG21, which may structurally stabilize the catalytic domain. All the molluscan GHF45 possess 12 Cys residues in common positions, suggesting that the stabilization by 6 disulfide bridges is a common feature among the GHF45 cellulases. Extremely high thermal stability of Cel45A from M. edulis, which withstands the heat-treatment at $100^{\circ} \mathrm{C}$ for $10 \mathrm{~min}$ (Xu et al., 2000), may be derived from such disulfide bonds. AkEG21 was also considerably heat stable probably due to the multiple disulfide formations.

In most organisms, cellulases are produced as modular enzymes made up of a catalytic domain and cellulose-binding domain(s) (CBD) that facilitates adsorption of the catalytic domain to insoluble cellulose (Gilkes et al., 1991; Henrissat and Davies, 2000). However, AkEG21 lacked cellulose-binding domain (CBD). Lack of CBD was also the cases of Cel45A from M. edulis (Xu et al., 2000), EG27 from A. crossean (Guo et al.,
2008) and CjCel45 from C. japonica (Sakamoto and Toyohara, 2009). Physiological meaning of the lack of CBD in molluscan GHF45 cellulases is currently obscure; however, low affinity of enzyme to cellulose substrate may rather suitable for the turnover of enzyme in the digestive fluid to digest amorphous seaweed cellulose.

Kinds of animal digestive enzymes appeared to be closely related to the staple foods of animals (Baldwin, 1949). However, distribution of cellulase in animal kingdom was found to be more closely related to their phylogenetic relationships than their feeding habits (Yokoe and Yasumasu, 1964). GHF45 cellulases have been found in fungi, bacteria, protists, and some invertebrate animals (Henrissat and Bairoch, 1993; http://www.cazy. org/Glycoside-Hydrolases.html). Phylogenetic analysis revealed that molluscan GHF45 cellulases and some fungal enzymes were clustered as a distinct group (Figure 7). Such clustering of molluscan GHF45 cellulases suggested that they have evolved from the same origin. Relatively close relation between molluscan cellulases and fungal cellulases suggests that molluscan enzymes were acquired by horizontal gene transfer from fungi as suggested by Sakamoto and Toyohara (2009). On the other hand, presence of potential N-glycosylation sites in all molluscan GHF45 cellulases is in common with some coleopteran cellulases may suggest that the molluscan cellulases share the common ancestor with insect GHF45 cellulases and have diverged from them during the evolutionary process (Davison and Blaxter, 2005; Watanabe and Tokuda, 2010). Rigorous investigation is necessary before concluding that the animal cellulases are acquired by horizontal gene transfer from fungi (Ochman et al., 2000; Genereux and Logsdon, 2003).

Besides AkEG21, a GHF9 cellulase of $45 \mathrm{kDa}$ was also found in the digestive fluid of $A$. kurodai (see Figure 1). Occurrence of multiple cellulase genes belonging to different GHFs in mollusks has already been reported (Zhang et al., 1999; Wang et al., 2003; Li et al., 2005; Sakamoto et al., 2007; Guo et al., 2008; Sakamoto and Toyohara, 2009) and synergistic action of multiple cellulases was recently reported (Tsuji et al., 2013). It may be reasonable to consider that herbivorous mollusks rely on plural cellulases to degrade cellulose to obtain carbohydrate nutrient from seaweeds. Indeed, the GHF9 cellulase of A. kurodai exhibited relatively higher specific activity compared with the GHF45 cellulase AkEG21 upon degradation of amorphous cellulose (Tsuji et al., 2013). Such differences in enzymatic properties were attributed to the differences in enzymatic parameters (Tsuji et al., 2013). The protein-engineering study on AkEG21 for application of this enzyme as biocatalyst for degradation of cellulosic materials from seaweeds is now under the investigation.

\section{ACKNOWLEDGMENTS}

This study was supported in part by the grants for project research (Construction of Marine Science Bases in Tohoku) of the Ministry of Education, Culture, Sports, Science and Technology, Japan.

\section{REFERENCES}

Agbor, V. B., Cicek, N., Sparling, R., Berlin, A., and Levin, D. B. (2011). Biomass pretreatment: fundamentals toward application. Biotechnol. Adv. 29, 675-685. doi: 10.1016/j.biotechadv.2011.05.005 
Baldwin, E. (1949). Dynamic Aspects of Biochemistry. London: Cambridge University Press.

Bayer, E. A., Belaich, J. P., Shoham, Y., and Lamed, R. (2004). The cellulosomes: multi-enzyme machines for degradation of plant cell wall polysaccharides. Ann. Rev. Microbiol. 58, 521-554. doi: 10.1146/annurev.micro.57.030502.091021

Bhat, M. K. (2000). Cellulases and related enzymes in biotechnology. Biotechnol. $A d v$. 18, 355-383. doi: 10.1016/S0734-9750(00)00041-0

Bisaria, V. S., and Mishra, S. (1989). Regulatory aspects of cellulase biosynthesis and secretion. Crit. Rev. Biotechnol. 9, 61-103. doi: 10.3109/07388558909040616

Bourne, Y., and Henrissat, B. (2001). Glycoside hydrolases and glycosyltransferases: families and functional modules. Curr. Opin. Struct. Biol. 11, 593-600. doi: 10.1016/S0959-440X(00)00253-0

Byrne, K. A., Lehnert, S. A., Johnson, S. E., and Moore, S. S. (1999). Isolation of a cDNA encoding a putative cellulase in the red claw crayfish Cherax quadricarinatus. Gene 239, 317-324. doi: 10.1016/s0378-1119(99)00396-0

Calderon-Cortes, N., Watanabe, H., Cano-Camacho, H., Zavala-Paramo, G., and Quesada, M. (2010). cDNA cloning, homology modelling and evolutionary insights into novel endogenous cellulases of the borer beetle Oncideresalbomarginata chamela (Cerambycidae). Insect Mol. Biol. 19, 323-336. doi: 10.1111/j.1365-2583.2010.00991.x

Cantarel, B. L., Coutinho, P. M., Rancurel, C., Bernard, T., Lombard, V., and Henrissat, B. (2009). The Carbohydrate-Active EnZymes database (CAZy): an expert resource for Glycogenomics. Nucleic Acids Res. 37, D233-D238. doi: 10.1093/nar/gkn663

Castresana, C., de Carvalho, F., Gheysen, G., Habets, M., Inze, D., and Montagu, M. V. (1990). Tissue-specific and pathogen-induced regulation of a Nicotiana plumbaginifolia $\beta$-1,3-glucanase gene. Plant Cell 2, 1131-1143. doi: $10.1105 /$ tpc.2.12.1131

Castresana, J. (2000). Selection of conserved blocks from multiple alignments for their use in phylogenetic analysis. Mol. Biol. Evol. 17, 540-552. doi: 10.1093/oxfordjournals.molbev.a026334

Cleveland, L. R. (1924). The physiological and symbiotic relationships between the intestinal protozoa of termites and their host, with special reference to Reticulitermes flavipes Kollar. Biol. Bull. 46, 177-215.

Davison, A., and Blaxter, M. (2005). Ancient origin of glycosyl hydrolase family 9 cellulase genes. Mol. Biol. Evol. 21, 1273-1284. doi: 10.1093/molbev/msi107

de la Cruz, J., Pintor-Toro, J. A., Benitez, T., Llobell, A., and Romero, L. C. (1995). A novel endo-beta-1,3-glucanase, BGN13.1, involved in the mycoparasitism of Trichoderma harzianum. J. Bacteriol. 177, 6937-6945.

Deville, C., Gharbi, M., Dandrifosse, G., and Peulen, O. (2007). Study on the effects of laminarin, a polysaccharide from seaweed, on gut characteristics. J. Sci. Food Agric. 87, 1717-1725. doi: 10.1002/jsfa.2901

Ding, M., Teng, Y., Yin, Q., Zhao, J., and Zhao, F. (2008). The N-terminal cellulosebinding domain of EGXA increases thermal stability of xylanase and changes its specific activities on different substrates. Acta Biochim. Biophys. Sin. 40, 949-954. doi: 10.1111/j.1745-7270.2008.00481.x

Elyakova, L. A. (1972). Distribution of cellulases and chitinases in marine invertebrates. Comp. Biochem. Physiol. B 43, 67-70. doi: 10.1016/0305-0491(72) 90202-7

Enquist-Newman, M., Faust, A. M., Bravo, D. D., Santos, C. N., Raisner, R. M., Hanel, A., et al., (2014). Efficient ethanol production from brown macroalgae sugars by a synthetic yeast platform. Nature 505, 239-243. doi: 10.1038/ nature12771

Fibriansah, G., Masuda, S., Koizumi, N., Nakamura, S., and Kumasaka, T. (2007). The $1.3 \AA$ crystal structure of a novel endo-beta-1,3-glucanase of glycoside hydrolase family 16 from alkaliphilic Nocardiopsis sp. strain F96. Proteins 69, 683-690. doi: 10.1002/prot.21589

Gavel, Y., and von Heijne, G. (1990). Sequence differences between glycosylated and non-glycosylated Asn-X-Thr/Ser acceptor sites: implications for protein engineering. Protein Eng. 3, 433-442. doi: 10.1093/protein/3.5.433

Genereux, D. P., and Logsdon, J. M. (2003). Much ado about bacteria-tovertebrate lateral gene transfer. Trends Genet. 19, 191-195. doi: 10.1016/S01689525(03)00055-6

Gilkes, N. R., Henrissat, B., Kilburn, D. G., Miller, R. C. Jr., and Warren, R. A. (1991). Domains in microbial beta-1,4-glycanases: sequence conservation, function, and enzyme families. Microbiol. Rev. 55, 303-315.

Girard, C., and Jouanin, L. (1999). Molecular cloning of cDNAs encoding a range of digestive enzymes from a phytophagous beetle, Phaedon cochleariae. Insect Biochem. Mol. Biol. 29, 1129-1142. doi: 10.1016/S0965-1748(99)00104-6
Gornall, A. G., Bardawill, C. J., and David, M. M. (1949). Determination of serum proteins by means of the biuret reaction. J. Biol. Chem. 177, 751-766.

Gueguen, Y., Chemardin, P., Labrot, P., Arnaud, A., and Galzy, P. (1997). Purification and characterization of an intracellular $\beta$-glucosidase from a new strain of Leuconostoc mesenteroides isolated from cassava. J. Appl. Microbiol. 82, 469-476. doi: 10.1046/j.1365-2672.1997.00136.x

Guo, R., Ding, M., Zhang, S. L., Xu, G. J., and Zhao, F. K. (2008). Molecular cloning and characterization of two novel cellulase genes from the mollusc Ampullaria crossean. J. Comp. Physiol. B 178, 209-215. doi: 10.1007/s00360-007-0214-z

Henrissat, B., and Bairoch, A. (1993). New families in the classification of glycosyl hydrolases based on amino acid sequence similarities. Biochem. J. 293, 781-788.

Henrissat, B., Claeyssens, M., Tomme, P., Lemesle, L., and Mornon, J. P. (1989). Cellulase families revealed by hydrophobic cluster analysis. Gene 81, 83-95.

Henrissat, B., and Davies, G. J. (2000). Glycoside hydrolases and glycosyltransferases. Families, modules, and implications for genomics. Plant Physiol. 124, 1515-1519. doi: 10.1104/pp.124.4.1515

Henrissat, B. A. (1991). A Classification of glycosyl hydrolases based on amino acid sequence similarities. Biochem. J. 280, 309-316.

Hong, T. Y., Cheng, C. W., Huang, J. W., and Meng, M. (2002). Isolation and biochemical characterization of an endo-1,3-beta-glucanase from Streptomyces sioyaensis containing a C-terminal family 6 carbohydrate-binding module that binds to 1,3-beta-glucan. Microbiology 148, 1151-1159.

Hurst, P. L., Nielsen, J., Sullivan, P. A., and Shepherd, M. G. (1977). Purification and properties of a cellulase from Aspergillus niger. Biochem. J. 165, 33-41.

Imjongjirak, C., Amparyup, P., and Sittipraneed, S. (2008). Cloning, genomic organization and expression of two glycosyl hydrolase family 10 (GHF10) genes from golden apple snail (Pomacea canaliculata). DNA Seq. 19, 214-236. doi: 10.1080/10425170701517911

Ito, S., Shikata, S., Ozaki, K., Kawai, S., Okamoto, K., Inoue, S., et al. (1989). Alkaline cellulase for laundry detergent: production by Bacillus sp. KSM-635 and enzymatic properties. Agric. Biol. Chem. 53, 1275-1281.

Jagtap, S., and Rao, M. (2005). Purification and properties of a low molecular weight $\beta$-1,4-glucan glucohydrolase having one active site for carboxymethyl cellulose and xylan from an alkalothermophilic Thermomonospora sp. Biochem. Biophys. Res. Commun. 329, 111-116. doi: 10.1016/j.bbrc.2005.01.102

Kikuchi, T., Jones, J., Aikawa, T., Kosaka, H., and Ogura, N. (2004). A family of glycosyl hydrolase family 45 cellulases from the pine wood nematode Bursaphelenchus xylophilus. FEBS Lett. 572, 201-205. doi: 10.1016/j.febslet.2004.07.039

Kovalchuk, S. N., Bakunina, I. Y., Burtseva, Y. V., Emelyanenko, V. I., Kim, N. Y., Guzev, K. V., et al. (2009). An endo-( $1 \rightarrow 3)-\beta-{ }_{-}$-glucanase from the scallop Chlamys albidus: catalytic properties, cDNA cloning and secondary-structure characterization. Carbohydr. Res. 344, 191-197. doi: 10.1016/j.carres.2008.10.028

Kovalchuk, S. N., Sundukova, E. V., Kusaykin, M. I., Guzev, K. V., Anastiuk, S. D., Likhatskaya, G. N., et al. (2006). Purification, cDNA cloning and homology modelling of endo-1,3- $\beta-D^{-}$-glucanase from scallop Mizuhopecten yessoensis. Comp. Biochem. Physiol. B 143, 473-485. doi: 10.1016/j.cbpb.2005.12.024

Kozhemyako, V. B., Rebrikov, D. V., Lukyanov, S. A., Bogdanova, E. A., Marin, A., Mazur, A. K., et al. (2004). Molecular cloning and characterization of an endo1,3- $\beta$-D-glucanase from the mollusk Spisula sachalinensis. Comp. Biochem. Physiol. B 137, 169-178. doi: 10.1016/j.cbpc.2003.10.018

Kuhad, R. C., Gupta, R., and Singh, A. (2011). Microbial cellulases and their industrial applications. Enzym. Res. 2011, 1-10. doi: 10.4061/2011/280696

Kumagai, Y., and Ojima, T. (2009). Enzymatic properties and the primary structure of a $\beta$-1,3-glucanases from the digestive fluid of the Pacific abalone Haliotis discus hannai. Comp. Biochem. Physiol. B 154, 113-120. doi: 10.1016/j.cbpb.2009.05.005

Kumagai, Y., and Ojima, T. (2010). Isolation and characterization of two types of beta-1,3-glucanases from the common sea hare Aplysia kurodai. Comp. Biochem. Physiol. B 155, 138-144. doi: 10.1016/j.cbpb.2009.10.013

Kumagai, Y., Satoh, T., Inoue, A., and Ojima, T. (2012). Enzymatic properties and primary structures of two $\alpha$-amylase isozymes from the Pacific abalone Haliotis discus hannai. Comp. Biochem. Physiol. B 164, 80-88. doi: 10.1016/j.cbpb.2012.11.001

Kumagai, Y., Satoh, T., Inoue, A., and Ojima, T. (2014). A laminaribiosehydrolyzing enzyme, AkLab, from the common sea hare Aplysia kurodai and its transglycosylation activity. Comp. Biochem. Physiol. B 167, 1-7. doi: 10.1016/j.cbpb.2013.07.008 
Larkin, M. A., Blackshields, G., Brown, N. P., Chenna, R., McGettigan, P. A., McWilliam, H., et al. (2007). Clustal $\mathrm{W}$ and Clustal X version 2.0. Bioinformatics 23, 2947-2948. doi: 10.1093/bioinformatics/ btm404

Li, L., Fröhlich, J., Pfeiffer, P., and König, H. (2003). Termite gut symbiotic archaezoa are becoming living metabolic fossils. Eukaryot. Cell 2, 1091-1098. doi: 10.1128/EC.2.5.1091-1098.2003

Li, Y., Yin, Q., Ding, M., and Zhao, F. (2009). Purification, characterization and molecular cloning of a novel endo- $\beta$-1,4-glucanases AC-EG65 from the mollusc Ampullaria crossean. Comp. Biochem. Physiol. B 153, 149-156. doi: 10.1016/j.cbpb.2009.02.011

Li, Y. H., Guo, R., Yin, Q. Y., Ding, M., Zhang, S. L., Xu, G. J., et al. (2005). Purification and characterization of two endo- $\beta$-1,4-glucanases from mollusca, Ampullaria crossean. Acta Biochem. Biophys. Sin. 37, 702-708. doi: 10.1111/j.1745-7270.2005.00099.x

Lowry, O. H., Rosebrough, N. J., Farr, A. L., and Randall, R. J. (1951). Protein measurement with the Folin phenol reagent. J. Biol. Chem. 193, 265-275.

Lynd, L. R., Weimer, P. J., vanZyl, W. H., and Pretorious, I. S. (2002). Microbial cellulose utilization: fundamentals and biotechnology. Microbiol. Mol. Biol. Rev. 66, 506-577. doi: 10.1128/MMBR.66.3.506-577.2002

Martin, M. M., and Martin, J. S. (1978). Cellulose digestion in the midgut of the fungus-growing termite Macrotermes natalensis: the role of acquired digestive enzymes. Science 199, 1453-1455. doi: 10.1126/science.199.4336.1453

Masuda, S., Endo, K., Koizumi, N., Hayami, T., Fukazawa, T., Yatsunami, R., et al. (2006). Molecular identification of a novel $\beta$-1,3-glucanase from alkaliphilic Nocardiopsis sp. strain F96. Extremophiles 10, 251-255. doi: 10.1007/s00792006-0514-3

Matthysse, A. G., Deschet, K., Williams, M., Marry, M., White, A. R., and Smith, W. C. (2004). A functional cellulose synthase from ascidian epidermis. Proc. Natl. Acad. Sci. U.S.A. 101, 986-991. doi: 10.1073/pnas.0303623101

Michel, G., and Czjzek, M. (2013). "Polysaccharide-degrading enzymes from marine bacteria," in Marine Enzymes for Biocatalysis: Sources, Biocatalytic Characteristics and Bioprocesses of Marine Enzymes, ed A. Trincone (Philadelphia, PA: Woodhead Publishing Series in Biomedicine, Number 38), 429-464.

Mojsov, K. (2012). Microbial cellulases and their applications in textile processing. Int. J. Mark. Technol. 2, 1219.

Nagano, N., Matsui, S., Kuramura, T., Taoka, Y., Honda, D., and Hayashi, M. (2011). The distribution of extracellular cellulase activity in marine Eukaryotes, thraustochytrids. Mar. Biotechnol. 13, 133-136. doi: 10.1007/s10126-010-9297-8

Nishida, Y., Suzuki, K., Kumagai, Y., Tanaka, H., Inoue, A., and Ojima, T. (2007). Isolation and primary structure of a cellulase from the Japanese sea urchin Strongylocentrotus nudus. Biochimie 89, 1002-1011. doi: 10.1016/j.biochi.2007.03.015

Ochman, H., Lawrence, J. G., and Groisman,. E. A. (2000). Lateral gene transfer and the nature of bacterial innovation. Nature 405, 299-304. doi: 10.1038/35012500

Ojima, T. (2013). "Polysaccharide-degrading enzymes from herbivorous marine invertebrates," in Marine Enzymes for Biocatalysis: Sources, Biocatalytic Characteristics and Bioprocesses of Marine Enzymes, ed A. Trincone (Philadelphia, PA: Woodhead Publishing Series in Biomedicine, Number 38), 333-371.

Park, J. T., and Johnson, M. J. (1949). A submicrodetermination of glucose. J. Biol. Chem. 181, 149-151.

Park, S. R., Cho, S. J., Kim, M. K., Ryu, S. K., Lim, W. J., An, C. L., et al. (2002). Activity enhancement of Cel5Z from Pectobacterium chrysanthemi PY35 by removing C-terminal region. Biochem. Biophys. Res. Commun. 291, 425-430. doi: 10.1006/bbrc.2002.6437

Pauchet, Y., Freitak, D., Heidel-Fischer, H. M., Heckel, D. G., and Vogel, H. (2009). Immunity or digestion: glucanase activity in a glucan-binding protein family from lepidoptera. J. Biol. Chem. 284, 2114-2124. doi: 10.1074/jbc.M806204200

Perez, J., Munoz-Dorado, J., de la Rubia, T., and Martinez, J. (2002). Biodegradation and biological treatments of cellulose, hemicellulose, and lignin: an overview. Int. Microbiol. 5, 53-63. doi: 10.1007/s10123-002-0062-3

Pesis, E., Fuchs, Y., and Zauberman, G. (1978). Cellulase activity and fruit softening in avocado. Plant Physiol. 61, 416-419. doi: 10.1104/pp.61.3.416

Porzio, M. A., and Pearson, A. M. (1977). Improved resolution of myofibrillar proteins with sodium dodecyl sulfate-polyacrylamide gel electrophoresis. Biochim. Biophys. Acta 490, 27-34. doi: 10.1016/0005-2795(77) 90102-7
Rahman, M. M., Inoue, A., Tanaka, H., and Ojima, T. (2010). Isolation and characterization of two alginate lyase isozymes, AkAly28 and AkAly33, from the common sea hare Aplysia kurodai. Comp. Biochem. Physiol. B 157, 317-325. doi: 10.1016/j.cbpb.2010.07.006

Ravindran, C., Naveenan, T., and Varatharajan, G. R. (2010). Optimization of alkaline cellulase production by the marine-derived fungus Chaetomium sp. Using agricultural and industrial wastes as substrates. Bot. Mar. 53, 275-282. doi: 10.1515/BOT.2010.026

Sakamoto, K., Touhata, K., Yamashita, M., Kasai, A., and Toyohara, H. (2007). Cellulose digestion by common Japanese freshwater clam Corbicula japonica. Fish. Sci. 73, 675-683. doi: 10.1111/j.1444-2906.2007.01381.x

Sakamoto, K., and Toyohara, K. (2009). Molecular cloning of glycoside hydrolase family 45 cellulase genes from brackish water clam Corbicula japonica. Comp. Biochem. Physiol. B 152, 390-396. doi: 10.1016/j.cbpb.2009.01.010

Scholl, E. H., Thorne, J. L., McCarter, J. P., and Bird, D. M. (2003). Horizontally transferred genes in plant-parasitic nematodes: a high-throughput genomic approach. Genome Biol. 4, R39.1-R39.12. doi: 10.1186/gb-2003-4-6-r39

Sheehan, J., and Himmel, M. (1999). Enzymes, energy, and the environment: a strategic perspective on the U.S. Department of Energy's research and development activities for bioethanol. Biotechnol. Prog. 15, 817-827. doi: 10.1021/bp990110d

Shimizu, E., Ojima, T., and Nishita, K. (2003). cDNA cloning of an alginate lyase from abalone, Haliotis discus hannai. Carbohydr. Res. 338, 2841-2852. doi: 10.1016/j.carres.2003.08.009

Smant, G., Stokkermans, J. P., Yan, Y., de Boer, J. M., Baum, T. J., Wang, X., et al. (1998). Endogenous cellulases in animals: isolation of $\beta$-1,4-endoglucanase genes from two species of plant-parasitic cyst nematodes. Proc. Natl. Acad. Sci. U.S.A. 95, 4906-4911. doi: 10.1073/pnas.95.9.4906

Sugimura, M., Watanabe, H., Lo, N., and Saito, H. (2003). Purification, characterization, cDNA cloning and nucleotide sequencing of a cellulase from the yellow spotted longicorns beetle, Psacothea hilaris. Eur. J. Biochem. 270, 3455-3460. doi: 10.1046/j.1432-1033.2003.03735.x

Suzuki, H., Suzuki, K., Inoue, A., and Ojima, T. (2006). A novel oligoalginate lyase from abalone, Haliotis discus hannai, that releases disaccharide from alginate polymer in an exolytic manner. Carbohydr. Res. 14, 1809-1819. doi: 10.1016/j.carres.2006.04.032

Suzuki, K., Ojima, T., and Nishita, K. (2003). Purification and cDNA cloning of a cellulase from abalone Haliotis discus hannai. Eur. J. Biochem. 270, 771-778. doi: 10.1046/j.1432-1033.2003.03443.x

Takeda, H., Yoneyama, F., Kawai, S., Hashimoto, W., and Murata, K. (2011). Bioethanol production from marine biomass alginate by metabolically engineered bacteria. Energy Environ. Sci. 4, 2575-2581. doi: 10.1039/C1EE01236C, Paper

Talavera, G., and Castresana, J. (2007). Improvement of phylogenies after removing divergent and ambiguously aligned blocks from protein sequence alignments. Syst. Biol. 56, 564-577. doi: 10.1080/10635150701472164

Tamura, K., Stecher, G., Peterson, D., Filipski, A., and Kumar, S. (2013). MEGA6: molecular evolutionary genetics analysis version 6.0. Mol. Biol. Evol. 30, 2725-2729. doi: 10.1093/molbev/mst197

Thomas, N. V., and Kim, S. K. (2013). Beneficial effects of marine algal compounds in cosmeceuticals. Mar. Drugs 11, 146-164. doi: 10.3390/md11010146

Tokuda, G., Lo, N., Watanabe, H., Slaytor, M., Matsumoto, T., and Noda, H. (1999). Metazoan cellulase genes from termites: intron/exon structures and sites of expression. Biochim. Biophys. Acta 1447, 146-159. doi: 10.1016/S01674781(99)00169-4

Tomme, P., Warren, R. A., and Gilkes, N. R. (1995). Cellulose hydrolysis by bacteria and fungi. Adv. Microb. Physiol. 37, 1-81. doi: 10.1016/S0065-2911(08)60143-5

Tsuji, A., Tominaga, K., Nishiyama, N., and Yuasa, K. (2013). Comprehensive enzymatic analysis of the cellulolytic system in digestive fluid of the Sea Hare Aplysia kurodai. Efficient glucose release from sea lettuce by synergistic action of $45 \mathrm{kDa}$ endoglucanase and $210 \mathrm{kDa}$ ß-glucosidase. PLoS ONE 8:e65418. doi: 10.1371/journal.pone. 0065418

van der Wal, H., Sperber, B. L., Houweling-Tan, B., Bakker, R. R., Brandenburg, W., and López-Contreras, A. M. (2012). Production of acetone, butanol, and ethanol from biomass of the green seaweed Ulva lactuca. Bioresour. Technol. 128, 431-437. doi: 10.1016/j.biortech.2012.10.094

Wang, J., Ding, M., Li, Y. H., Chen, Q. X., Xu, G. J., and Zhao, F. K. (2003). Isolation of a multifunctional endogenous cellulase gene from mollusc, Ampullaria crossean. Acta Biochim. Biophys. Sin. 35, 941-946. 
Wang, J., and Gao, P. (2000). In vitro expression of Penicillium janthinellum cellobiohydrolase I gene in a coupled transcription-translation system. J. Biotechnol. 81, 205-209. doi: 10.1016/S0168-1656(00)00285-6

Wang, W., Wang, S. X., and Guan, H. S. (2012). The antiviral activities and mechanisms of marine polysaccharides: an overview. Mar. Drugs. 10, 2795-2816. doi: $10.3390 / \mathrm{md} 10121795$

Wargacki, A. J., Leonard, E., Win, M. N., Regitsky, D. D., Santos, C. N., Kim, P. B., et al. (2012). An engineered microbial platform for direct biofuel production from brown macroalgae. Science 335, 308-313 doi: 10.1126/science.1214547

Watanabe, H., Noda, H., Tokuda, G., and Lo, N. (1998). A cellulase gene of termite origin. Nature 394, 330-331. doi: 10.1038/28527

Watanabe, H., and Tokuda, G. (2001). Animal cellulases. Cell. Mol. Life Sci. 58, 1167-1178. doi: 10.1007/PL00000931

Watanabe, H., and Tokuda, G. (2010). Cellulolytic systems in insects. Ann. Rev. Entomol. 55, 609-632. doi: 10.1146/annurev-ento-112408-085319

Wei, Y. D., Lee, K. S., Gui, Z. Z., Yoon, H. J., Kim, I., Je, Y. H., et al. (2006). $\mathrm{N}$-linked glycosylation of a beetle (Apriona germari) cellulase Ag-EGase II is necessary for enzymatic activity. Insect Biochem. Mol. Biol. 36, 435-441. doi: 10.1016/j.ibmb.2006.03.007

Wong, T. Y., Preston, L. A., and Schiller, N. L. (2000). ALGINATE LYASE: review of major sources and enzyme characteristics, structure-function analysis, biological roles, and applications. Annu. Rev. Microbiol. 54, 289-340. doi: 10.1146/annurev.micro.54.1.289

Xu, B., Hellman, U., Ersson, B., and Janson, J. C. (2000). Purification, characterization and amino-acid sequence analysis of a thermostable, low molecular mass endo- $\beta$-1,4-glucanase from blue mussel, Mytilus edulis. Eur. J. Biochem. 267, 4970-4977. doi: 10.1046/j.1432-1327.2000.01533.x

$\mathrm{Xu}, \mathrm{B}$. , Janson, J. C., and Sellos, D. (2001). Cloning and sequencing of a molluscan endo-beta-1,4glucanase gene from the blue mussel, Mytilus edulis. Eur. J. Biochem. 268, 3718-3727. doi: 10.1046/j.1432-1327.2001.02180.x

Yan, Y., Smant, G., Stokkermans, J., Qin, L., Helder, J., Baum, T., et al. (1998). Genomic organization of four $\beta$-1,4-endoglucanase genes in plant-parasitic cyst nematodes and its evolutionary implications. Gene 210, 61-70. doi: 10.1016/S0378-1119(98)00413-2

Yanagisawa, M., Kawai, S., and Murata, K. (2013). Strategies for the production of high concentrations of bioethanol from seaweeds: production of high concentrations of bioethanol from seaweeds. Bioengineered 4, 214-235. doi: 10.4161/bioe. 23396
Yanagisawa, M., Ojima, T., and Nakasaki, K. (2011). Bioethanol from sea lettuce with use of crude enzymes derived from waste. J. Mat. Cycl. Waste Man. 14, 321-326. doi: 10.1007/s10163-011-0026-9

Yang, B., Dai, Z., Ding, S. Y., and Wyman, C. E. (2011). Enzymatic hydrolysis of cellulosic biomass. Biofuels 2, 421-450. doi: 10.4155/bfs.11.116

Yokoe, Y., and Yasumasu, I. (1964). The distribution of cellulase in invertebrates. Comp. Biochem. Physiol. 13, 323-338. doi: 10.1016/0010-406X(64)90027-1

Zahura, U. A., Rahman, M. M., Inoue, A., Tanaka, H., and Ojima, T. (2010). An endo- $\beta$-1,4- mannanase, AkMan, from the common sea hare Aplysia kurodai. Comp. Biochem. Physiol. B 157, 137-143. doi: 10.1016/j.cbpb.2010.05.012

Zahura, U. A., Rahman, M. M., Inoue, A., Tanaka, H., and Ojima, T. (2011). cDNA cloning and bacterial expression of an endo- $\beta-1,4$-mannanase, AkMan, from Aplysia kurodai. Comp. Biochem. Physiol. B 159, 217-235. doi: 10.1016/j.cbpb.2011.05.001

Zaldivar, J., Nielsen, J., and Olsson, L. (2001). Fuel ethanol production from lignocellulose: a challenge for metabolic engineering and process integration. Appl. Microbiol. Biotechnol. 56, 17-34. doi: 10.1007/s002530100624

Zhang, Z., Zhao, H., Zhou, X. W., Chen, L. F., Chen, T. S., and Chen, Q. X. (1999). Preliminary studies on isolation, purification and some properties of $\beta$-glucosidase from Ampullarium crossean. J. Xiamen. Univ. 38, 287-291.

Conflict of Interest Statement: The authors declare that the research was conducted in the absence of any commercial or financial relationships that could be construed as a potential conflict of interest.

Received: 18 June 2014; paper pending published: 28 June 2014; accepted: 15 July 2014; published online: 06 August 2014.

Citation: Rahman MM, Inoue A and Ojima T (2014) Characterization of a GHF45 cellulase, AkEG21, from the common sea hare Aplysia kurodai. Front. Chem. 2:60. doi: 10.3389/fchem.2014.00060

This article was submitted to Chemical Biology, a section of the journal Frontiers in Chemistry.

Copyright (C) 2014 Rahman, Inoue and Ojima. This is an open-access article distributed under the terms of the Creative Commons Attribution License (CC BY). The use, distribution or reproduction in other forums is permitted, provided the original author(s) or licensor are credited and that the original publication in this journal is cited, in accordance with accepted academic practice. No use, distribution or reproduction is permitted which does not comply with these terms. 